\title{
Tabanidae (Diptera) of Iran X. List, Keys and Distribution of Species occurring in Iran

By Rosemarie ABBASSIAN-LINTZEN (**)

\section{INTRODUCTION}

This paper is a revisional study of the Iranian tabanid species, many of which have been already reported and treated in the writer's previous papers (AbbassianLintzen, 1960-1964). It is also an effort to gather new and additional records and to bring up to date all available taxonomical and ecological knowledge concerning our horsefly fauna. It is based on some 3.100 specimens, which have been accumulated in the insect collection of the I.P., Tr. Med. and Hyg. mostly during the last 5-years. The present list of 67 species and 12 subspecies should not be regarded as final since other species and genera, which occur in the neighbouring countries, may eventually be found in Iran.

A little more than half of the 41 species, reported as occurring in Iran by various authors during the last decades and listed by the present writer in the beginning of her work on Tabanidae (1960 A), have been re-collected during this 5-years study. Not considered in this list are the remainders of the species, several of which may be of doubtful occurrence in Iran and others of which are probably of doubtful validity. However, the more recent records of Hybomitra erberi erberi $\mathrm{Br}$. and Tabanus mouchaei Lecl., both reported as Iranian species by Philip and Leclercq respectively, but not found by this writer, are included here.

In this paper a new species, a new subspecies and eight species, which formerly have not been known to occur in this country, are added to the Iranian faunal list : Das. umbrinus Mg., H. sewelli Aust., Ther. albicaudus Ols., T. assuetus Haus., T. bactrianus Ols., T. olsufjevi Haus., T. sordes B. and S. and T. tergestinus Egg. The Ethio-

(*) This study is supported in part by the Endemic Diseases Project of the Ministry of Health and Plan Organization (Project 631101), and in part by the Institute of Parasitolgy, Tropical Medicine and Hygiene, Tebran University, School of Medicine, Iran (formerly Institute of Parasitolgy and Malariology)

$(* *)$ Chief of Laboratory, Division of Entomology, Institute of Parasitology, Tropical Medicine and Hygiene, P.O. Box 1310, Tehran (Iran). 
pian $T$. taeniola Pal.-B. is delated from the list as well as $N$. abbassianae Lecl., T. armeniacus $\mathrm{Kr}$., $T$. inaequatus Aust. and $H$. pluvialis elbursiensis Abb.-L. The latter 4 species are now correctly identified as $N$. caucasicus molitor B. and S., T. indrae Haus., Hyb. pecularis Szil. and $H$. hispanica Szil. These corrections were made possible through the aid of Prof. N. G. Olsufjev, who forwarded for comparison a large and beautiful collection of Tabanidae mostly from the Caucasus and Central Asia and informed us about the synonymous status of $N$. abbassianae, $T$. inaequatus and $H$. pluvialis elbursiensis. Mr. H. Oldroyd's gift of four specimens of T. taeniola from Africa proved that our determination of an Iranian species as this Ethiopan form was erroneous : it represents smaller specimens of $T$. atropathenicus Ols.

\section{LIST OF IRANIAN SPECIES BASED ON RECENT COLLECTIONS}

(Only records reported in the literature subsequent to 1958 are considered)

\section{Subfamily Chrysopinae Tribe Chrysopini}

1. Silvius ochraceus Lw., 2. Nemorius caucasius molitor Bog. and Sam., 3. N. horvathi Szil., 4. N. irritans Ric., 5. N. shapuricus Abb.-L., 6. N. vitripennis Mg., 7. Chrysops caecutiens ludens Lw., 8. Chr. flavipes flavipes Mg., Chr. flavipes gedrosiana n. subsp., Chr. flavipes punctifer Lw., Chr. flavipes simillimus Aust.

\section{Subfamily Tabaninae, Tribe Diachlorini}

9. Dasyrhamphis umbrinus $\mathrm{Mg}$.

\section{SUbFamILy Tabaninae, TrIBE Haematopotini}

10. Haematopota atropathenica Abb. L., 11. H. caspica Abb.-L., 12. H. grandis iranica Abb.-L., 13. H. hispanica Szil., 14. H. minuscula Aust., 15. H. pallens Lw., 16. H. sewelli Aust.

\section{SUbFAmILY Tabaninae, TRIBE Tabanini}

17. Atylotus agrestis agrestis Wied., At. agrestis afghanistanicus M. and Chv., 18. At. karybenthinus Szil., 19. At. pulchellus Lw., 20. At. theodori n. sp., 21. Hyb. (Sipala) acuminata Lw., 22. Hyb. erberi erberi Br., Hyb. erberi obscura Ols., 23. Hyb. glaber Big., 24. Hyb. pecularis Szil. 25. Hyb. olsoufievi Phil. (new name for Hyb. tetrica Szil.), 26. Therioplectes albicaudus Ols., 27. Ther. carabaghensis Port., 28. Tabanus accipiter Szil., 29. T. ansarii ansarii Abb.-L., T. ansarii gedrosiae Abb.-L., T. ansarii nigrinervis Abb.-L., 30. T. anthrax Ols., 31. T. assuetus Haus., 32. T. autumnalis brunnescens Szil., 33. T. atropathenicus Ols., 34. T. bactrianus Ols., 35. T. bromius bromius L., T. bromius flavofemoratus Str., 36. T. canipalpis Big., 37. T. capito Ols., 38. T. cordiger Mg., 39. T. bifarius Lw., 40. T. glaucopis Mg., 41. T. gratus Lw., 42. T. indrae Haus., 43. T. kermani Abb.-L., 44. T. laetitinctus Beck., 45. T. leclercqi Abb.-L., 46. T. leleani leleani Aust., T. leleani pallidus Ols., 47. T. miki miki Br., T. miki australis Haus., 48. T. mistshenkoi Ols., 49. T. mofidii mofidii Lecl., T. mofidii atrofemoratus Abb.-L., 50. T. mouchaei Lecl., 51. T. olsufjevi Haus., 52. T. 
oppugnator Aust., 53. T. pallidipes Aust., 54. T. polygonus Walk., 55. T. quatornotatus Mg., 56. T. regularis Jaen., 57. T.? rupinae Aust., 58. T. sabuletorum Lw., 59. T. semenovi Ols., 60. T. shelkovnikovi shelkovnikovi Par., T. shelkovnikovi meridionalis Abb.-L., 61. T. sordes B. and S., 62. T. spectabilis Lw., 63. T. sufis Jaen., 64. T. tergestinus Walk., 65. T. tinctus Walk., 66. T. unifasciatus Lw., 67. T. zimini Ols.

\section{THE COMPOSITION OF THE IRANIAN HORSEFLY FAUNA}

After a glance a the above list it is evident that Iran, as an arid country and at the present stage of its entomological exploration, has a good-sized tabanid fauna. It is rich especially in the genus Tabanus with its 40 species. Here the remarkable frequency of sand coloured forms like $T$. bromius flavofemoratus, $T$. kermani, T. laetitinctus, $T$. leclercqi, T. mofidii, T. pallidipes, $T$. polygonus and $T$. ? rupinae, almost all of which have yellowish femora, may very well be a reflection of the desert-like appearance particular to the Iranian landscape. The paucity of hairy-eyed species like $\mathrm{Hybo-}$ mitra and Tabanus species belonging to the nemoralis-group can be accounted for by the dry air and hot climate of Iran. With one exception ( $T$. quatuornotatus), hairy-eyed species (Hyb. olsoufievi, Ther. carabaghensis and T. oppugnator) have been observed only at well vegetated, cool and humid mountain valleys of North and West Iran or on the wet, lush littoral of the Caspian sea (Ther. albicaudus). Even in Hybomitra pecularis which shows a prominent pile of eye hairs in the temperate regions of Europe, the amount of ocular hairiness is decreased to an almost negligible degree in Iranian specimens.

Other notable features of the Iranian fauna are the absence of the genus Pangonius and the presence of such a large quantity of Nemorius species. The first phenomenon is in agreement with the fauna of several other countries of the Eastern Mediterranean subregion like Iraq, Palestine and Egypt and with the distant regions more eastwards e.g. the Kazakistan SSR, where no Pangonius is recorded either. An explanation for this is easily found, if one looks at Oldroyd's (1957) map no. II (p. 52). The four tribes of Tabanidae which now exist in Iran : Chrysopini, Diachlorini, Haematopotini and Tabanini have reached our country from Europe and the Mediterranean area; and there they came in an arched movement from North and South America, the latter subcontinent being Oldroyd's hypothetical homeland of the family Tabanidae. The said four tribes spread into Iran and farther east towards the Oriental Region after branching into the Ethiopan Region. Only the genus Pangonius of the more primitive tribe Pangoniini left South America in a northern direction and reached Europe, probably branching into two sections: one went to North Africa through Spain, the second one penetrated into Central and South Europe up to Asia Minor and the Caucasus, but did not touch Egypt, Palestine and more eastern regions.

The fact that the genus Nemorius is represented with 5 species in one country appears to be unique. Philip (1961) has suggested that a burst of speciation in Nemorius occurred in the Middle East. Now it may be added, that this was especially the case in 
Iran. The chart below shows the distribution picture of the different tabanid genera in Iran and its surrounding countries as far their various faunistic elements are known to us up to date. In comparing the peculiarities of these countries or geographical areas one has to bear in mind that the fauna of Iran, and particularly those of Iraq and Afghanistan, are more or less poorly explored so far.

\section{Distribution OF THE GENERA OF TABANIDAE in the Eastern Mediterranean Subregion}

\begin{tabular}{|c|c|c|c|c|c|c|c|c|c|}
\hline \multirow[b]{2}{*}{ Genera } & \multicolumn{9}{|c|}{ Number of species } \\
\hline & Greece & Turkey & $\begin{array}{c}\text { Azer- } \\
\text { baijan } \\
\text { S.S.R. } \\
\left({ }^{*}\right)\end{array}$ & $\begin{array}{c}\text { Kaza- } \\
\text { kistan } \\
\text { S.SR. }\end{array}$ & $\begin{array}{l}\text { Afgha- } \\
\text { nistan }\end{array}$ & Iran & Iraq & $\begin{array}{l}\text { Pales- } \\
\text { tine }\end{array}$ & Egypt. \\
\hline Pangonius ... & 7 & 9 & - & - & 一 & - & - & - & 一 \\
\hline Silvius ..... & 2 & 4 & 3 & - & 1 & 1 & 一 & - & - \\
\hline Nemorius ... & - & 3 & 1 & 1 & 2 & 5 & 1 & - & - \\
\hline Chrysops ... & 5 & 4 & 5 & 14 & 2 & 2 & 1 & 3 & - \\
\hline Dasyrh. .... & 4 & 4 & 1 & - & - & 1 & - & 2 & 1 \\
\hline Haematopota & 8 & 7 & 9 & 5 & 1 & 7 & 1 & 5 & 1 \\
\hline Atylotus ... & 5 & 5 & 8 & 7 & 1 & 4 & 4 & 1 & 5 \\
\hline Hybomitra . & 8 & 4 & 8 & 26 & 7 & 5 & 3 & 5 & 一 \\
\hline Therioplectes & 2 & 2 & 4 & - & - & 2 & 一 & 1 & 一 \\
\hline Tabanus ... & 28 & 29 & 40 & 20 & 9 & 40 & 14 & 14 & 8 \\
\hline Total - & 69 & 70 & 79 & 72 & 23 & 67 & 24 & 31 & 15 \\
\hline
\end{tabular}

The fauna of Iranian Tabanidae represents on interesting mixture of Mediterranean, European, Asiatic, endemic and a few Ethio-asian elements as the following analysis will show. Of the 67 species and 12 subspecies $=79$ forms listed above for Iran, 27 forms are common to the Mediterranean subregion (11 of these only to its eastern parts), 16 forms are not found outside of Iran, they are therefore to be considered as endemic, 2 are known presently only from certain restricted areas (Mesopotamia and Caspian Sea littoral) and 12 occur in Iran and Transcaucasia. Ten forms are Central Asiatic, 5 are European and 4 are Mongolian elements. Two others inhabit the dryer parts of the Ethiopian Region and the southeastern Mediterranean area and one form is widely distributed in the Ethiopian and the warmer parts of the Palaearctic Region. Except for the latter three, all these horseflies are purely Palaearctic; no Oriental element has invaded from the Southeast. As far as our present knowledge goes,

(*) Inclusive Nakhichevan ASSR. 
the related families Asilidae and Bombyliidae and the Ixodoidea (ticks) of Iran belong to the same zoogeographical regions. But we do not find this distributional pattern in regard to the Anophelinae and $\mathrm{Ph}$ !ebotominae of this country, from which several and one species respectively have spread from the Oriental Region to Iran and farther west.

The various faunistic elements which constitute the Iranian Tabanidae are the followings :

\section{Mediterranean elements $(34,17 \%)$}

A. WITH A WIDE RANGE

1. N. vitripennis

2. Chr. caecutiens ludens

3. Chr. flavipes flavipes

4. Chr. flavipes punctifer

5. Das. umbrinus

6. At. pulchellus

7. T. autumnalis brunnescens

8. T. bifarius
9. T. bromius flavofemoratus.

10. T. leleani

11. T. quatuornotatus

12. $T$. regularis

13. T. spectabilis

14. T. tinctus

15. T. tergestinus

16. T. unifasciatus

B. Eastern Mediterranean only

17. S. ochraceus

18. N. horvathi

19. N. irritans

20. Chr. flavipes simillimus

21. H. minuscula

22. H. pallens
23. H. sewelli

24. T. oppugnator

25. $T$. pallidipes

26. T. laetitinctus

27. T. rupinae

\section{Endemic elements $(22,78 \%)$}

1. N. shapuricus

2. Chr. flavipes gedrosiana

3. H. atropathenica

4. H. caspica

5. H. grandis iranica

6. At. theodori

7. T. canipalpis

8. T. kermani

9. T. leclercqi
10. T. ansarii ansarii

11. T. ansarii gedrosiae

12. T. ansarii nigrinervis

13. T. mofidii mofidii

14. T. mofidii atrofemoratus

15. T. mouchaei

16. T. shelkovnikovi meridionalis

17. T. polygonus (Mesopotamia)

18. Ther. albicaudus (Caspian Sea littoral : S. and S.W. part)

\section{Irano-Transcaucasian elements $(15,18 \%)$}

1. N. caucasicus molitor

2. Ther. carabaghensis
3. Hyb. olsoufievi (?)

4. T. anthrax 
5. T. assuetus

6. T. atropathenicus

7. T. capito

8. T. indrae
9. T. miki australis

10. T. olsufjevi

11. T. shelkovnikovi shelkovnikovi

12. T. sordes

\section{Central Asiatic elements $(12,65 \%)$}

1. At. agrestis afghanistanicus

2. At. karybenthinus

3. Hyb. erberi obscura

4. Hyb. glaber

5. T. accipiter
6. T. bactrianus

7. T. leleani pallidus

8. T. mistshenkoi

9. T. semenovi

10. T. zimini

\section{European elements $(6,31 \%)$}

1. H. hispanica

2. T. bromius bromius

3. T. cordiger
4. T. glaucopis

5. T. miki miki

\section{Mongolian elements $(5,06 \%)$}
1. Hyb. acuminata
2. Hyb. erberi erberi

3. Hyb. pecularis

4. T. sabuletorum

\section{Ethio-asian elements $(3,79 \%)$}

1. At. agrestis agrestis

2. T. gratus

3. T. sufis

Considering the above data, we see that about one third of the Iranian fauna belongs to the Mediterranean Subregion and about one fourth seems to be endemic. The reason for the high frequency of Mediterranean elements may be the fact, that southern Iran (Khuzistan, Fars, Kerman province and Baluchistan) is one of the best explored region to date. The extended landstrip from Sistan up to Mashhad along the border of Afghanistan and Turkmenia SSR to the east of the great central Iranian desert (Kavir and Lut) is nearly completely unworked. There, more Central Asiatic forms will be probably discovered as well as in Khorassan in the N.E. and in the steppes of the Gorgan plain, both of which have been searched only very superficially. The oases of the great salt desert and its bordering localities may shelter an interesting desert fauna. The chains of the Zagros and Elburz and the mountains of Azerbaijan will certainly reveal more Transcaucasian species if properly investigated. One of the best known regions of Iran is the Caspian Sea coast with its rich cultivated fields and large, dense forests, which result from a very high annual precipitation. Surprisingly, here one meets with a tabanid fauna which shows an extremely high frequency in specimens, but which is very monotonous in species. The open fields are inhabited mainly by 
$T$. autumnalis brunnescens and Chr. caecutiens ludens, the forests by large swarms of H. caspica. Other species like Ther. albicaudus, H. pallens, At. agrestis agrestis, T. cordiger, $T$. tergestinus and $T$. bifarius (the latter on mountain-steppes) have been observed only occasionally.

\section{KEY TO THE GENERA OF IRANIAN TABANIDAE (BOTH SEXES)}

1. Hind tibiae with 2 apical spurs like those of the middle tibiae; wing: basicosta bare (Chrysopinae:

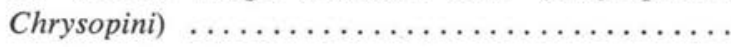

- Hind tibiae without apical spurs; wings: basicosta bare or with hairs (black or yellow) like those on the costal vein (Tabaninae) $\ldots \ldots \ldots \ldots \ldots \ldots \ldots \ldots$

2. Wings with dark patterns ; body yellow-black .....

- Wings hyaline ; body yellow or greyish .........

3. Frons narrow; eyes in life (or relaxed) freckled; palpi without longitudinal groove; body entirely

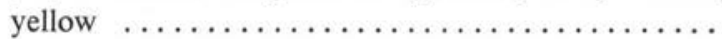

- Frons broader; eyes in life (or relaxed) ringed with a central spot; palpi with a \pm deep longitudinal groove ; body greyish $\ldots \ldots \ldots \ldots \ldots \ldots \ldots \ldots$.

4. Wing : basicosta bare; body robust, blackish (Dia-

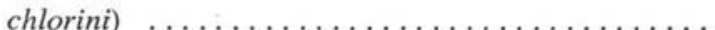

- Wing : basicosta with hairs (black or yellow) like those on the costal vein ; body slender to robust and usually not blackish, variable in colour .........

5. 3rd. antennal segment with 3 distinct annuli; wings with a pattern of light spots and streaks often forming rosettes ; eyes in life (or relaxed) with irregular

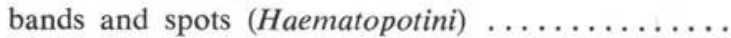

- 3rd. antennal segment with 4 distinct annuli ; wings usually hyaline, seldom tinted or fumose ; eyes in life (or relaxed) banded or unicolorous (Tabanini) ..

Chrysops Meigen.

Silvius Meigen.

Nemorius Rondelli.

Dasyrhamphis Enderlein.

Haematopota Meigen.

6. Eyes in life (or relaxed) faintly greenish, translucent, with dark shifting, internal spots ; in dried specimens yellow to rusty brown. Frons (q) with small, spot-like, isolated calli ; small to moderately sized (7-14 $\mathrm{mm})$, yellowish-grey delicate flies .........

Atylotus Enderlein.

- Eyes in life (or relaxed) greenish or black, never translucent and without spots, blackish when dried (in certain males only lower area of small facets). 
Frons ( $(+)$ with a large, prominent lower callus ; small to large $(7-25 \mathrm{~mm})$, mostly greyish, but sometimes blackish or yellow-brown flies $\ldots \ldots \ldots \ldots \ldots \ldots$.

7. $q$ : vertex with one distinct, denuded ocellar tubercle or with 3 smaller ones; $\sigma^{*}$ : vertex with an elevated, anteriorly shining tubercle; eyes in life (or relaxed) always with 3 purple bands $\ldots \ldots \ldots \ldots \ldots \ldots$.

- $q$ : vertex without ocellar tubercle; $\delta$ : vertex with a completely tomented tubercle; eyes in life (or relaxed) with 1-4 (5) purple (and sometimes partly blue) bands or unbanded $\ldots \ldots \ldots \ldots \ldots \ldots \ldots$.

Hybomitra Enderlein.

8. Middle and hind tibiae broadened and densely covered with white hairs. Large, bumble-bee-like species with yellow-brown tinted wings $\ldots \ldots \ldots \ldots \ldots \ldots$.

- Middle and hind tibiae normal and with short black or grey hairs. Small to large, Tabanus-like species, usually with hyaline wings $\ldots \ldots \ldots \ldots \ldots \ldots \ldots$ Tabanus Linnaeus.

\section{SUBFAMILY CHRYSOPINAE, TRIBE CHRYSOPINI}

\section{Genus Silvius Meigen}

Silvius ochraceus Loew, 1858, is the only species of the genus Silvius recognized in Iran. This rare and completely yellow species, which lacks even one dark hair, has freckled eyes in life. The male is unknown, $q$ h have been found attacking domestic animals at about $1800 \mathrm{~m}$ alt. in southern Iran. It does not come straight forward like a Tabanus fly: before attacking it hovers restlessly around the animal like a Bembex wasp, but is completely soundless.

Distribution in Iran : Kerman province, Fars.

General distribution: Turkey, Iran.

\section{Genus Nemorius Rondelli}

Key to THE SPECIES OF THE GENUS Nemorius

Females

1. No parantennal, bare calli on either side of anten-

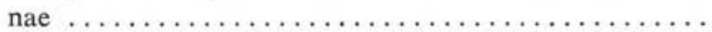

- Parantennal calli present...$\ldots \ldots \ldots \ldots \ldots \ldots \ldots$

N. caucasicus molitor (Bogachev and Samedov).

2. Halteres and veins yellow; 2nd. antennal segment

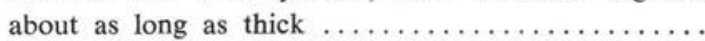




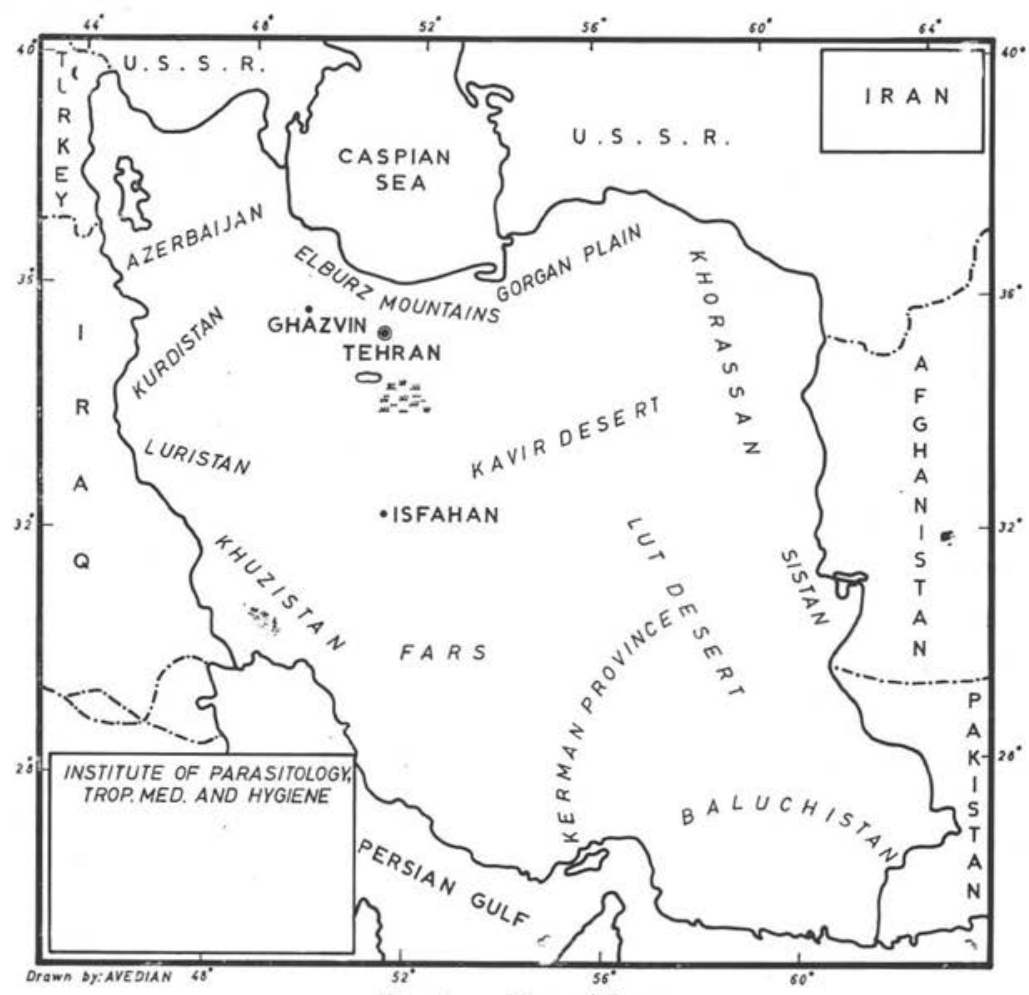

FIG. 1. - Map of Iran

- Halteres and veins brown; 2nd. antennal segment about twice as long as thick $\ldots \ldots \ldots \ldots \ldots \ldots \ldots$

3. Parantennal calli small and doubled: two on either side of antennae; parafacial pores distinct ........

- Parantennal calli large and undivided: one on either side of antennae, parafacial pores lacking ..........

N. irritans (Ricardo).

N. shapuricus

(Abbassian-Lintzen).

4. Frons usually with «nebencalli ; parantennal calli touching ocular margins; parafacial pores fine and

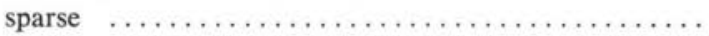

N. vitripennis Meigen.

— Frons always without «nebencalli»; parantennal calli usually narrowly separated from ocular margins ; parafacial pores coarse and distinct $\ldots \ldots \ldots \ldots \ldots$.

N. horvathi Szilady.

\section{MALES}

The males of $N$. irritans, $N$. shapuricus and $N$. horvathi are not known, the key is therefore incomplete. 
1. 2nd. antennal segment as long as thick or a little lon-

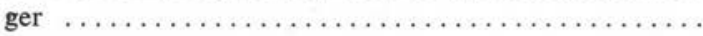

- 2nd. antennal segment twice as long as thick N. caucasicus molitor (Bog. et Sam.). N. vitripennis $\mathrm{Mg}$.

Nemorius caucasicus molitor (Bogachev and Samedov), 1949, syn. (*) : N. abbassianae Leclecq, 1960.

This species has been reported by Leclecq and the present writer as $N$. abbassianae Lecl. Philip noted the close relationship of $N$. abbassianae and $N$. caucasicus molitor (1961, p. 234). After examination of a specimen of abbassianae, which we sent to him, Prof. Olsufjev expressed his opinion (in litt. : 8.1.63. and 20.X.63.) that abbassianae is identical with caucasicus molitor. We studied a specimen of the latter on loan from Prof. Olsufjev. There are differences between the two forms in total length of antennae, deepness of palpal groove and shape of frontal callus, but we did not know, if these characters are constant or within the limit of variation. Prof. Olsufjev indicated (correspondence : 20.X.63.) that there occur not only intermediate forms between caucasicus molitor and caucasicus caucasicus at the same localities, but that also the above mentioned characters of antennae, palpal groove and frontal callus \& are not constant in this species and therefore they have not a specific significance $\$$. N. abbassianae is therefore considered to be a synonym of $N$. caucasicus molitor and the name is deleted from the list of Iranian species.

Distribution in Iran : Fars (at one locality occurring together with $N$. irritans and N. shapuricus).

General distribution: USSR (Nakhichevan ASSR), Iran.

Nemorius irritans (Ricardo), 1901.

This small species and Chr. flavipes simillimus are most troublesome to bathers in southern Iran. It has been observed mostly in the vicinity of saline breeding places and seems to be halophile.

Distribution in Iran: E. Khorassan (type locality), Baluchistan, Fars, Khuzistan, Azerbaijan.

General distribution: Iran, Afghanistan, Iraq, Turkey.

Nemorius shapuricus (Abbassian-Lintzen), 1960.

Nearly related to previous species, $N$. shapuricus has been found to date only at its type locality and is probably a localized, endemic form.

Distribution in Iran : Fars.

General distribution : Iran.

Nemorius vitripennis Meigen, 1820 ; syn. : N. bouvieri Philip, 1961.

A pair and two series of this species were taken by the writer in mountain valleys near Neishapur, Mashhad and Ghuchan (alt. : 1400-1 $600 \mathrm{~m}$, all localities in N. Khorassan) in July 1961. Philip's type material originated from Bar, a village ab. $40 \mathrm{~km}$

(*) Only names recently synonymized are mentioned in this paper. 
N. of Neishapur. Prof. Olsufjev saw a specimen from the Ghuchan series and stated (in litt. : 8.1.63.) that it is identical with $N$. vitripennis, which species is « widely distributed and variable ». Later he confirmed this opinion a second time (correspondence: 20.X.63.). We possess no extra-Iranian material to compare our indigenous smaller form with, but accepting Olsufjev's judgement $N$. bouvieri is placed in synonymy with N. vitripennis.

Distribution in Iran : Khorassan.

General distribution: Central and South Europe, USSR (Caucasus, southern Turkestan), Iran.

Nemorius horvathi Szilady, 1926.

Distribution in Iran : Elburz Mountains, Kerman province, Fars.

General distribution: Turkey, Iran.

\section{Genus Chrysops Meigen}

KEY TO THE SPECIES OF THE GENUS Chrysops

\section{Females}

1. Discal cell dark, without fenestrate spot $\ldots \ldots \ldots \ldots$ Chr. (s. str.) caecutiens ludens Loew.

- Discal cell with a distinct clear spot (Heterochrysops

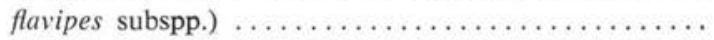

2. Winzs: apical spot about equal in size or a little narrower than costal and subcostal cells together, prolonged towards midlength of $r_{4}$ without passing over midlength of same or only covering appr. apical

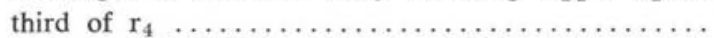

- Wing: apical spot distinctly larger than costal and subcostal cells together, prolonged towards midlength of $r_{4}$, covering about apical three-fourth of length

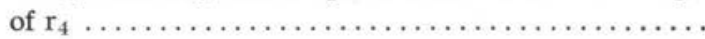

3. Facial calli black or black-brown; 2nd. tergite with 2 wedge-shaped, oblique, black stripes, which do not touch anteriorly; wing: basal half of cell $\mathrm{R}_{2}+{ }_{3}$ (1st. submarginal cell) uniformly darkened ...........

Chr. flavipes flavipes Meigen.

- Facial calli dirty yellowish; 2nd. tergite with 2 black, narrow, arched stripes, which are connected anteriorly and like an upturned lyre; wing: basal third of cell $\mathrm{R}_{2}+{ }_{3}$ (1st. submarginal cell) much lighter in colour, only slightly darkened

Chr. flavipes gedrosiana $\mathrm{n}$. subsp.

4. Basal half of cell $R$. darkened $\ldots \ldots \ldots \ldots \ldots \ldots$ Chr. flavipes punctifer Loew.

- Only extreme basis of cell $\mathrm{R}$ darkened Chr. flavipes simillimus Austen. 


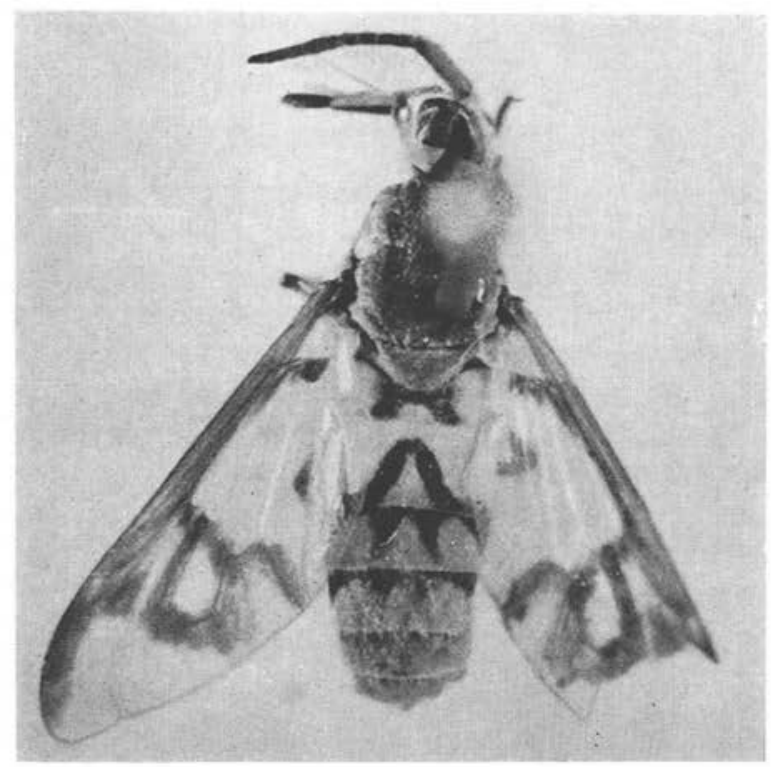

Fig. 2. - Chrysops flavipes gedrosiana n. subsp. (Phot. D ${ }^{r}$ A. Razavi)

\section{MaLes}

The male of Chr. flavipes gedrosiana n. subsp. is unknown.

1. Discal cell dark, without fenestrate spot $\ldots \ldots \ldots \ldots$.

- Discal cell with a dinstinct clear spot (Heterochrysops flavipes subspp.)

2. Wing apical spot about equal in size as costal and subcostal cells together, prolonged towards midlength of $r_{4}$ without passing over midlength of same or only covering appr. apical third of $r_{4} \ldots \ldots \ldots \ldots \ldots$

- Wing: apical spot distinctly larger than costal and subcostal cells together, prolonged towards midlength of $r_{4}$, covering apical three-fourth of length of $r_{4} \ldots$.

3. Dorsum of abdomen yellow and black coloured; 2nd. tergite with 2 large, lateral, yellow spots; 3 rd. and 4th. tergite with 2 smaller, lateral spots ..........

- Dorsum of abdomen predominantly black coloured; 2nd. tergite with 2 small, yellow spots; 3 rd. and 4th. tergite black laterally, lacking spots ..........
Chr. (s. str.) caecutiens ludens Loew.

Chr. flavipes flavipes $\mathrm{Mg}$.

Chr. flavipes punctifer Lw.

Chr. flavipes simillimus Aust. 
Chrysops (Chr.) caecutiens ludens Loew, 1858.

Distribution in Iran : Caspian Sea coast ; Gorgan plain (VI.-IX.). Crimea, Caucasus), Iran.

Chrysops flavipes flavipes Meigen, 1804.

Distribution in Iran : Azerbaijan, Isfahan.

General distribution : S. Europe, N. Africa, Asia Minor, USSR (Caucasus, S. Russia, Central Asia), Iran.

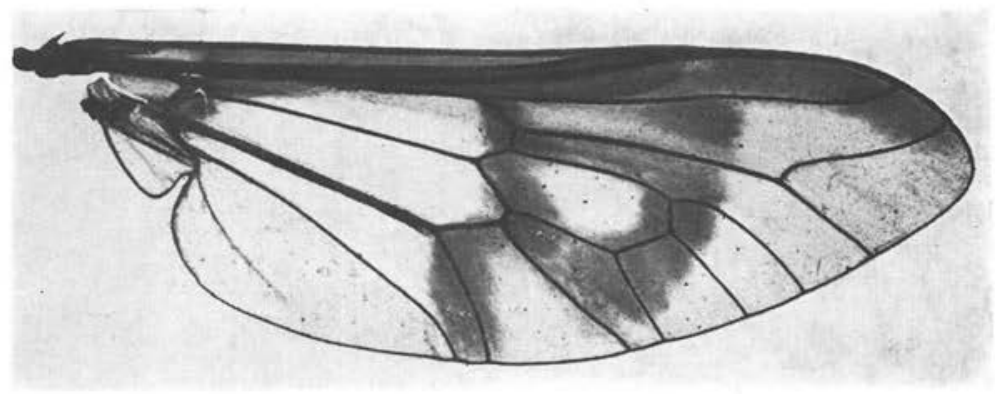

Fig. 3. - Wing of Chrysops flavipes gedrosiana n. subsp. (Phot. D $\mathrm{D}^{\mathrm{r}}$ A. Razavi)

\section{Chrysops flavipes gedrosiana n. subsp.}

This in 1960 discovered form of the polytypic Chr. flavipes is that, which we reported as an undescribed subspecies of simillimus (Abbassian-Lintzen, 1961 A, p. 133). It differs from the nominal form, simillimus and punctifer in the characters given in the key. It may be added that in the Baluchistanian subspecies the sternites are completely yellow and coxae II and III are yellowish, not blackish-grey. All observed characters are uniform in the obtained series and all the specimens show no tendency to intergrade with any of the other subspecies of flavipes.

Length of body : 6-8,5 mm.

Holotype : female, Kuluk, Saravan (Baluchistan), 12.V.1960., donkey, Abbassian coll. ; paratypes : 51 q, ibidem, 12., 19. and 29.V.60., donkeys ; 1 , Damin, Iranshahr (Baluchistan), 13.IV.60., donkey.

Chrysops flavipes punctifer Loew, 1856.

Distribution in Iran: Fars, Khuzistan, Khorassan, Kurdistan, Isfahan, Ghazwin, ? Baluchistan (as maculiventris Becker).

General distribution: Central and Southern Europe, North Africa, Asia Minor, Palestine, Syria, Cyprus, USSR (Caucasus, Central Asia), Iran.

Chrysops flavipes simillimus Austen, 1923.

Distribution in Iran : Fars, Kerman province, Khuzistan.

General distribution : Iraq, Iran. 


\section{SUBFAMILY TABANINAE TRIBE DIACHLORINI}

\section{Genus Dasyrhamphis Enderlein}

Dasyrhamphis umbrinus (Meigen), 1820, is the only species of the genus Dasyrhamphis recorded in Iran. In 1958 the insect collection of the Institute contained 2 우 of this species without label, which had obviously been taken in Iran by one of our malaria workers. I never observed the species in nature up to the present. These two specimens (one, which lost its antennae during dispatch, is now in the collection of Dr. M. Leclercq, Beyne-Heusay) are not completely identical with umbrinus : in both $q \circ$ the subcallus is entirely covered by grey tomentum, the wings are nearly colourless and the palpi a little more inflated. They may prove to be an undescribed subspecies, but since they are slightly denuded of hairs and any indication of their origin is lacking, it is prefered to consider them provisionally as being of the typical form. Dasyrhamphis umbrinus has not been recorded from Iran previously.

Distribution in Iran :

General distribution: S. Europe, Turkey, Palestine, USSR (Caucasus, Central Asia), Iran.

\section{SUBFAMILY TABANINAE TRIBE HAEMATOPOTINI}

\section{KEY TO THE SPECIES OF THE GENUS Haematopota}

\section{Females}

1. 1st. antennal segment long, cylindrical, never swollen but sometimes «knotted»; distinctly more than 3,5 times longer than thick, nearly as long as frontal

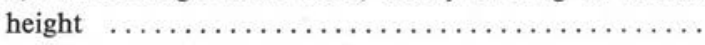

- 1st. antennal segment short and swollen, distinctly less than 3 times longer than thick, much shorter than frontal height $\ldots \ldots \ldots \ldots \ldots \ldots \ldots \ldots \ldots \ldots \ldots \ldots \ldots \ldots$

2. Third antennal segment narrower than first segment; the latter often with more than one stricture and with humps, giving segment a « knotted appearance ; wing: pale continuous border of posterior margin broad; pale streaks, spots and rosettes much more extensive; apical streak sometimes doubled or broad-

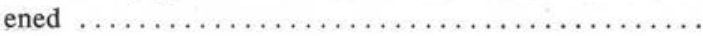

H. pallens Loew.

- Third antennal segment as thick or thicker than first segment; the latter never with more than one stricture, never with humps, segment always smooth; wing: pale continuous border of posterior margin 
narrow; pale streaks, spots and rosettes much reduced; apical streak always simple, never broadened ..

3. Posterior border of wing margin with a continuous broad, pale border $\ldots \ldots \ldots \ldots \ldots \ldots \ldots \ldots \ldots \ldots \ldots \ldots \ldots \ldots \ldots$

- Posterior border of wing margin without a continuous broad, pale border .. ..................

4. Two black spots on face absent; first antennal segment about 1,5 times as long as thick; apical half of same black brillant, basal half grey tomented ......

- Two black spots on face present ; first antennal segment 2,5 times as long as thick and wholly grey tomented on a black giound $\ldots \ldots \ldots \ldots \ldots \ldots \ldots$

5. Frons distinctly narrower than width of one eye; first antennal segment apically shining; wings dark brown with pale patterns $\ldots \ldots \ldots \ldots \ldots \ldots \ldots \ldots$

- Frons distinctly broader than width of one eye ; first antennal segment completely covered with tomentum ; wings greyish with pale patterns...$\ldots \ldots \ldots$.

6. First antennal segment entirely black-grey coloured;

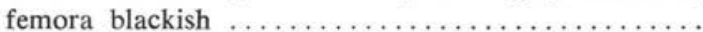

- First antennal segment brown-reddish at inner surface ; middle and hind femora pinkish-grey ........
H. grandis iranica AbbassianLintzen.

4

5

H. minuscula Austen.

H. atropathenica, Abbassian-Lintzen.

H caspica Abbassian-Lintzen.

H. hispanica Szilady.

H. sewelli Austen.

\section{MaLes}

The males of $H$. grandis iranica, $H$. minuscula, $H$. atropathenica and $H$. caspica are not known. The key is therefore incomplete.

1. Wing: posterior border of wing margin with a continuous broad, pale border; antennae: $3 \mathrm{rd}$. segment

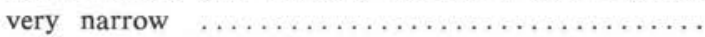

H. pallens Lw.

- Wing: posterior border of wing margin without a continuous broad, pale border; antennae: 3 rd. seg-

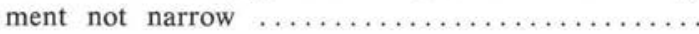

2. Antennae: 1st. segment ovoid and completely covered above by grey tomentum $\ldots \ldots \ldots \ldots \ldots \ldots \ldots \ldots$

- Antennae : 1st. segment very swollen and black brilliant at apex, slightly tomented at basis.

H. hispanica Szil.

H. sewelli Aust.

Haematopota pallens Loew, 1870.

This common species of South Iran is also recorded in mountainous parts of North Iran. Its immature stages seem to tolerate saline conditions to a great extent. Specimens 
from Fars and Khuzistan show a slight taxonomical difference to those from northern parts and Baluchistan: the frons is somewhat narrower, the 1st. antennal segment is not as « knotted " and broad and the wings have never a doubled apical transverse streak. Our collecting records date from 20. April to 9. October.

Distribution in Iran : Baluchistan, Kerman province, Fars, Khuzistan, Azerbaijan, Caspian Sea littoral (? rare), Gorgan p'ain, Khorassan. Alt. : appr. 100-1 800 m.

General distribution: USSR (Ukraine, Crimea, Caucasus, Central Asia), Iran, Iraq.

Haematopota grandis iranica Abbassian-Lintzen, 1960.

This is perhaps an endemic form of grandis, but Olsufjev (correspondence : 8.I.63.) thinks it to be more related to pallens. Resembling also H. pavlovskii Hauser, 1960.

Distribution in Iran : Fars, Tehran, Azerbaijan (800-1 $800 \mathrm{~m}$ alt.).

General distribution : Iran.

Haematopota minuscula Austen, 1919.

Apparently a localized southern species.

Distribution in Iran : Fars : Khuzistan (alt. appr. sea level to $1200 \mathrm{~m}$ ).

General distribution: Palestine, Iran.

Haematopota atropathenica Abbassian-Lintzen, 1964.

Distribution in Iran : Azerbaijan, Fars (alt. : 1 800-2 $030 \mathrm{~m}$ ).

General Distribution : Iran.

Haematopota caspica Abbassian-Lintzen, 1960.

We propose to consider $H$. caspica, described as a subspecies of $H$. pluvialis, as a distinct and separate species, since large series have been collected from many localities without any evidence of transient forms. Prof. Olsufjev (8.I.63.) has the opinion that it is remote from pluvialis and belongs to the variegata-group. It is a most distinct species of great taxonomical stability and inhabits the coast of the Caspian Sea (mountain forests and cultivated plains). Our records date from 21. June to 20. September.

Distribution in Iran: Caspian Sea littoral.

General Distribution : Iran.

Haematopota hispanica Szilady, 1923, syn. : H. pluvialis elbursiensis AbbassianLintzen, 1960.

Prof. Olsufjev wrote (8.I.63.) that the female of $H$. pluvialis elbursiensis (Abe Ali, Elburz Mountains, 23.VI.59.) sent to him « is identical with $H$. hispanica Szil. ».

Distribution in Iran : Elburz Mountains.

General distribution: Central and Southern Europe, USSR (Caucasus, Western Siberia, Northern Kazakistan), Iran.

Haematopota sewelli Austen, 1919.

3 우 of this have been collected at Abe Ali, Elburz Mountains (23.-26.VI.59.) by the author. Dr. Leclercq identified them as $H$. sewelli (in litt. : 19.I.62.).

Distribution in Iran: Elburz Mountains.

General distribution : Palestine, ? Greece, Iran . 


\title{
IV. SUBFAMILY TABANINAE, TRIBE TABANINI
}

\author{
6. Genus Atylotus Enderlein \\ Key to THE SPEC!ES OF THE genus Atylotus
}

\section{Females}

1. Ground colour of tergite III-VII unicolorous yellow without dark grey median stripe; dark pattern (on tergite I and II) not covered by dark hairs; relati-

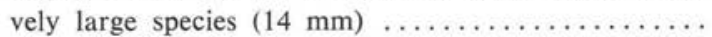

- Ground colour of tergite I-VII usually with a broad dark grey to blackish longitudinal median stripe (only some very light coloured specimens of At. agrestis afghanistanicus, small race : $6-8 \mathrm{~mm}$, may lack a dark median stripe); dark pattern (on tergite I-VII) partly covered by dark hairs; smaller species (6-14 mm)

At. theodori n. sp.

2. Rim of occiput with long, forwardly bent hairs; tergites covered by thick, whitish tomentum ..........

- Rim of occiput with short, inconspicuous, erect hairs ; tergites covered by thin, yellowish tomentum ......

3 . Tergites with 4 longitudinal rows of small, wedge-shaped spots, which do not reach posterior margin of tergites; veins in the basal half of wing yellow, in the apical half brownish

At. pulchellus Loew.

- Tergites with 4 longitudinal rows of larger, wedgeshaped spots, which do reach posterior margins of tergites; veins entirely yellow $\ldots \ldots \ldots \ldots \ldots \ldots$.

4. Dorsum of abdomen with 4 uninterrupted longitudinal (2 paramedian and 2 sublateral) stripes of nearly equal width, which consist of dark hairs; large,

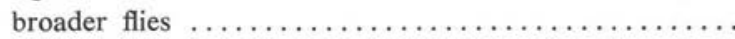

At. agrestis agrestis Wiedemann.

- Dorsum of abdomen with 2 longitudinal (paramedian) stripes consisting of dark hairs, which are \pm interrupted and of irregular width: broader at anterior borders of tergites and very narrow (often faded away) at midlenght and posterior borders of tergites; sublateral stripes are sometimes indicated by an indistinct, dark haired spot on tergite I-III $\ldots \ldots \ldots \ldots \ldots \ldots$

5. Small, very slender, delicate flies $(6-8 \mathrm{~mm}) \ldots \ldots \ldots$

- Larger, stouter $(10-11 \mathrm{~mm})$ flies $\ldots \ldots \ldots \ldots \ldots \ldots \ldots$

At. karybenthinus Szilady.

\section{5}

At. agrestis afghanistanicus Moucha and Chvala, small race.

At. agrestis afghanistanicus Moucha and Chvala, large race. 


\section{MaLES}

The males of At. theodori n. sp. and At. agrestis afghanistanicus M. and Chv. are unknown.

1. Rim of occiput with a fringe of short hairs; eyes

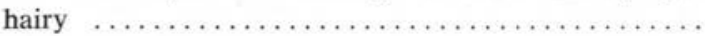

- Rim of occiput with a fringe of long, forwardly bent

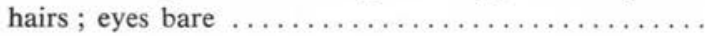

At. agrestis W.

2. Tergites with 4 longitudinal rows of small, wedgeshaped spots, which do not reach posterior margin of tergites; veins in the basal half of wing yellow, in the apical half brownish $\ldots \ldots \ldots \ldots \ldots \ldots \ldots$.

- Tergites with 4 longitudinal rows of larger, wedgeshaped spots, which do reach posterior margins of tergites; veins entirely yellow

2

At. pulchellus L.

At. karybenthinus Szil.

\section{Atylotus theodori n. sp.}

It is not without hesitation that we propose a new species of the problematic genus Atylotus, which Palaearctic members lack good structural characters to a great degree and which show usually very frail abdominal patterns. But the present species could not be placed with any of the (formerly or recently) described species of this genus. Thank to its collector the present specimen is in an excellent condition and possesses rather distinct taxonomical characters. In order that it may be identified At. theodori is recognized as andescribed species.

If Kröber's identification key of females (1938, p. 186) is reliable, our species would key to the group where the dark coloured abdominal pattern is never covered by dark hairs. It seems to belong to the agricola group, but is does not agree with any of the species of this group due to the situation of its lower callus, the almost parallel sided frons, the very strongly to tergite I and II reduced middle stripe in the dark yellow ground colour and the completely yellow legs incl. coxae. On the other hand, according to description and figures $A t$. theodori n. sp. shows similarity to At. farinosus Szil. (Efflatoun Bey, 1930, p. 61-64, fig. 63 and plate I, fig. 8) and At. kröberi Surc. (Kröber, 1925, p. 80). From the former it is easily distinguished by the almost parallel sided frons, the lack of whitish tomentum and the dark pattern in the ground colour of tergite I and II. It differs from At. kröberi in having 4 distinct dark haired abdominal stripes and a very narrow (much narrower than width of scutellum) dark longitudinal stripe on tergite II.

Female. - Head : large, hemispheric. Eyes bare, yellow in the dried specimen, with a trace of one narrow purple eye band. Frons almost parallel sided, proportions : 7:5,5:23 ; index : 4,2 ; yellowish tomented and with yellow hairs all over and black ones at upper three-fifth of frons. Lower and upper callus separated, small, dot-like, shining black-brown, the lower one in a distance from subcallus. Subcallus and face with light 
yellow tomentum, the latter with glistening short yellow hairs; buccae with tomentum of same colour and white-yellow haired. Antennae yellow, basal segment lighter in colour and with black hairs above and thinner, yellowish hairs below; 3rd. segment with the very blunt dorsal hump situated almost at midlength of segment. Palpi yellowwhite, terminal segment rather swollen in basal half, then slender and elongated, pointed, with glistening yellow-white and stronger black hairs. Rim of occiput fringed with stiff short yellowish hairs.

Thorax : mesonotum and scutellum black in ground colour, grey tomented, unstriped, densely covered by recumbent, golden-yellow and erect black hairs. Notopleural

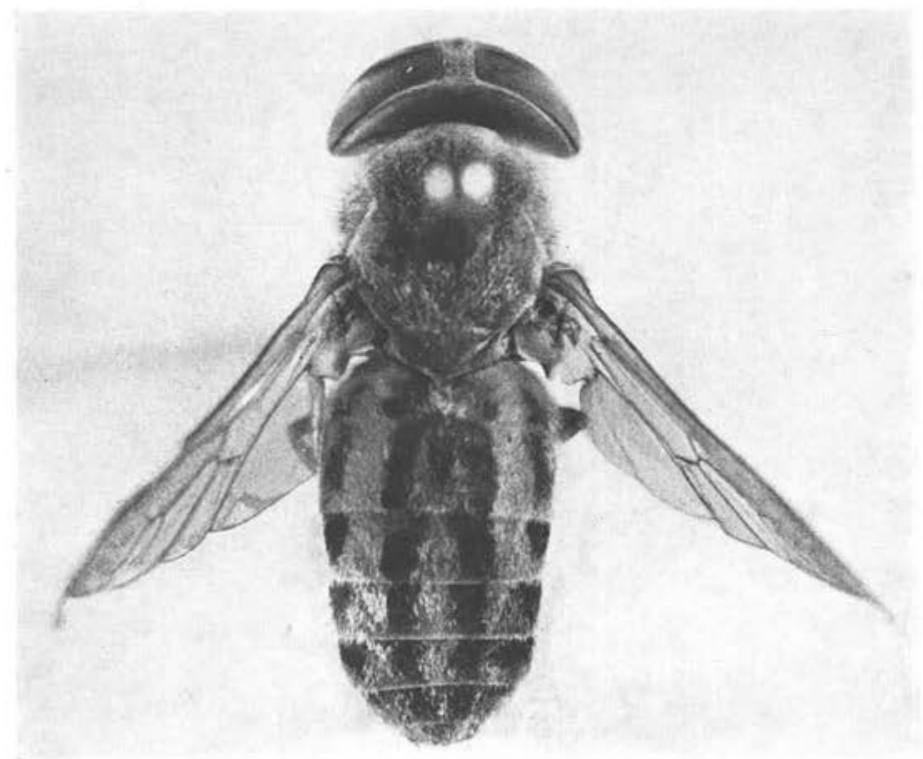

FIG. 4. - Atylotus theodori n. sp. (Phot. D ${ }^{r}$ A. Razavi)

lobe yellow in ground colour, thinly covered by yellowish tomentum, mostly with erect black hairs. Pleura greyish tomented and with long yellowish hairs. Wings hyaline, $\mathrm{r}_{4}$ with a long appendix, veins yellow. Basicosta and extreme basal part of costa with yellow and black setae. Halteres yellow, knobs white-yellow. Legs : coxae not like pleura, but yellow in ground colour and tomentum. Rest of legs of same colour except tarsi, which appear dark brown due to dense black hairs. Fore femora laterally and above with long black and glistening yellow hairs, medially with short black hairs ; middle and hind femora with predominantly yellow hairs and a few scattered black ones.

Abdomen: predominantly dark yellow in ground colour, only tergite I with a small dark grey spot situated under each side of tip of scutellum and tergite II with a 
narrow (ab. one tenth of tergal width) longitudinal median stripe, which reaches a little over midlength of tergite. Posterior margins of tergite I-VI with very narrow lighter coloured borders. All tergites with thin yellowish tomentum and predominantly yellow haired. Dorsum of abdomen with a conspicuous pattern of 4 longitudinal (2 paramedian and 2 sublateral) dark stripes consisting of black hairs on the dark yellow ground. The darkened parts on tergite I and II are covered with yellow hairs only. Last tergite with a mixture of yellow and black hairs as usual. Venter : light yellow in ground colour except a small, dark grey, median spot on anterior part of sternite II. Posterior border of sternite I-VI very narrowly lighter yellow coloured. All sternites with yellow hairs, last sternite with several erect black ones.

Length of body (excl. ant.) : $14 \mathrm{~mm}$, length of wings : $10 \mathrm{~mm}$.

Holotype female, Insheburun, Gonbad-Ghabus (Gorgan Plain, N. Iran), ab. sea level, 18.VII.61., in car, coll. : Prof. O. Theodor, Jerusalem. In the collection of I.P., Trop. Med. and Hyg., Tehran.

MaLE : unknown.

It is with great p easure to name this species in honour of Prof. Oskar Theodor of Jerusalem, the well known authority on Phlebotominae and Pupipara, who during his scientific visit to Iran placed this and other interesting, here collected specimens of Tabanidae at our disposal.

Distribution : Iran.

Atylotus pulchellus (Loew), 1858.

Common in southern Iran, recorded from sea level up to $1600 \mathrm{~m}$ altitude, often in the vicinity of saline water.

Distribution in Iran : Baluchistan, Kerman province, Sistan, Fars, Khuzistan, Gorgan Plain.

General distribution : Asia Minor, Iraq, Cyprus, Sardinia, Egypt, N. Africa, USSR (Central Asia, Transcaucasia), Iran.

Atylotus karybenthinus (Szilady), 1915.

Apparently rare in Iran.

Distribution in Iran : Khuzistan.

General distribution : USSR (Central Asia, Mongolia, Manchuria), Iran, Afghanis$\tan (2$ $\$$ recorded for the first time from the latter country ; coll. : Dr. Ch. Mofidi, see also At. agrestis afghanistanicus).

Atylotus agrestis agrestis (Wiedemann), 1828.

The typical form of this species seems to be rare in Iran, only one specimen is recorded.

Distribution in Iran : Caspian Sea littoral.

General distribution: Southern Europe, Egypt, Africa, Arabia, USSR (Southern part of European USSR, Caucasus, Central Asia), Iran, India, Far East. 
Atylotus agrestis afghanistanicus Moucha and Chvala, 1959, large race.

The 120 specimens collected at Sabsevar (Khorassan) on 14.X.57. from a donkey by a local collector agree very well with 7 specimens from Kabul, Afghanistan (behind window pane at airport, Sept. 1961, coll. : Dr. Ch. Mofidi), which represent Moucha and Chvala's subspecies without doubt. They differ from the following smaller race by their broader and shorter abdomen. The present form is recorded for the first time from Iran.

Distribution in Iran : Khorassan.

General distribution : Afghanistan, Iran.

Atylotus agrestis afghanistanicus M. and Chv., 1959, small race.

In southern Iran this small race with its elongated and delicate body is rather common and no specimen of neither the large race of agrestis afghanistanicus nor of agrestis agrestis seems to occur there. As noted by the writer (Abbassian-Lintzen, 1961 A, p. 134) these specimens are smaller and show hardly 2 sublateral rows of dark spots. It is not impossible that the present form has been previously described under any of the numerous names given in the synonymy by Oldroyd (1954, p. 114-115), Kröber (1925, p. 76) and Efflatoun Bey (1930, p. 52). Since neither the type specimens of these nor their original descriptions are available to me, I have to be content to mention this form here as a «small race of agrestis afghanistanicus ».

Distribution in Iran : Baluchistan, Fars, Khuzistan.

General distribution : not known.

\section{Genus Hybomitra Enderlein}

KEY TO THE SPECIES OF THE GENUS Hybomitra

\section{Females}

1. Last 3 abdominal segments laterally compressed ....

- Last 3 abdominal segments not compressed, but square

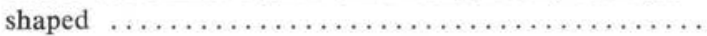

2. Body uniformly black inclusive halteres $\ldots \ldots \ldots \ldots$

- Body not uniformly black: abdomen laterally reddish and halteres whitish to yellowish..$\ldots \ldots \ldots \ldots$

3. Dorsum of abdomen with a narrow (about a sixth to a tenth of width of segment), dark, longitudinal stripe ; sternite II lacking a dark median spot ............

- Dorsum of abdomen with a broader (about a third to a fourth of width of segment), dark, lontgitudinal stripe ; sternite II with a dark, median spot or venter with $\mathrm{a} \pm$ sharp, longitudinal stripe $\ldots \ldots \ldots \ldots \ldots \ldots$

4. All antennal segments entirely velvety black; frons narrow (index 5) and lower callus touching eye mar-
Hyb. (Sipala) acuminata Loew.

2

Hyb. olsoufievi Philip.

Hyb. pecularis Szilday. 
gin at lower frontal extremity; frons very slightly divergent toward vertex ; first posterior cell of wing very much narrowed apically; femora distally only narrowly reddish-yellow $\ldots \ldots \ldots \ldots \ldots \ldots \ldots$.

- At least 1st. and 2 nd. antennal segment reddish yellow; frons broader (index 4-4,5) and lower callus never touching eye margin, but distinctly separated from latter; frons stronger divergent toward vertex; first posterior cell of wing wide open or slightly narrowed apically; femora distally broadly (ab. a third of lenght) reddish-yellow $\ldots \ldots \ldots \ldots \ldots \ldots \ldots \ldots$.

Hyb. glaber Bigot.

5. Sides of dorsum of abdomen till tergite IV or V reddish ; venter : only a dark median spot on sternite II

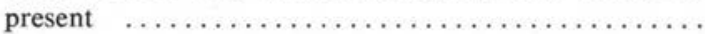

- Sides of dorsum of abdomen only till tergite III reddish ; venter with $\mathrm{a} \pm$ sharp, dark, longitudinal

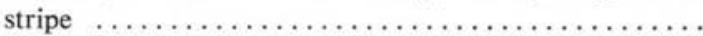

Hyb. erberi erberi Brauer.

Hyb. erberi obscura

Olsufjev.

\section{MALES}

The males of Hybomitra glaber and Hyb. erberi obscura are unknown.

1. Head relatively large, hemispheric. Last abdominal segments sometimes laterally compressed ..........

- Head normal. Last abdominal segments never laterally

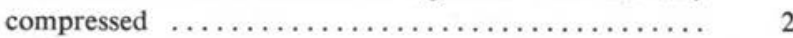

2. Body uniformly black inclusive halteres ......... Hyb. olsoufievi $\mathrm{Ph}$.

- Body not uniformly black; abdomen laterally reddish and halteres whitish to yellowish $\ldots \ldots \ldots \ldots \ldots \ldots \ldots$

3. 2nd. sternite entirely yellow ..................... Hyb. pecularis Szil.

- 2nd. sternite with a dark median spot ............ Hyb. erberi Br.

Hybomitra (Sipala) acuminata (Loew), 1858.

Obviously rare in Iran.

Distribution in Iran : Sistan, Azerbaijan.

General Distribution: S. Europe, USSR (Caucasus, Central Asia), Mongolia, Iran.

Hybomitra olsoufievi Philip, 1956 (new name for Hyb. tetrica Szilady, the latter preoccupied by Marten).

Distribution in Iran : Elburz Mountains.

General distribution : Central Europe, Caucasus, Iran.

Hybomitra pecularis (Szilady), 1914, syn. : Tabanus inaequatus Austen, 1923.

After studying one female of « $T$. inaequatus from Jarrahi (Dashte-Mishan, Khuzistan, 22.V.62.), Prof. Olsufjev wrote (correspondence : 8.I.63.) : «Tabanus inae- 
quatus Aust., 1923, 1 \%, is identical with Tabanus pecularis Szilady, 1914 ». Close examination and comparison (external and internal - genitalia - characters) of pecularis and « inaequatus " carried out subsequently led to the result that Prof. Olsufjev's judgement is completely correct. The Khuzistan specimens do not differ significantly from pecularis (from Greece, Danube Delta, Kazakistan and Iranian Azerbeijan), they are only smaller in size. The name "Tabanus inaequatus » is therefore considered a synonym.

Distribution in Iran : Khuzistan and Azerbeijan (saline swamps, alt. : sea level and $1300 \mathrm{~m})$.

General distribution : Southern Europe, USSR (S.E. of European USSR, Caucasus, Central Asia), Mongolia, Iran, Iraq.

Hybomitra glaber (Bigot), 1892.

Tabanus glaber has a bare ocellar tubercle with 3 minute oval vestigal ocelli. This character and the structure of head, frons, antennae and palpi and the colouration of abdomen indicates that it should be transferred to Hybomitra. It is allied to Hyb. erberi, but easily to distinguish from the latter by characters given in the key. Furthermore it seems to differ bio.ogically, too, in obviously being an « autumn-species 》 (AbbassianLintzen, 1963 , p. 83). Hybomitra glaber fits very well in Olsufjev's succession of Hybomitra species (Olsufjev, 1937, p. 200 and 391), in which the gradual reduction of the ocellar tubercle and eye hairs is obvious : montanus-mühlfeldi-nigrivitta-erberiglaber-pecularis.

Distribution in Iran : Sistan, Khuzistan.

Generai distribution: Afghanistan, Chinese Turkestan, Iraq, Iran.

Hybomitra erberi erberi (Brauer), 1880.

Apparently rare in Iran.

Distribution in Iran : Gorgan plain.

General distribution: Southern Europe, USSR (Crimea, Caucasus, S.E. of European USSR, Central Asia), Mongolia, Iran.

Hybomitra erberi obscura (Olsufjev), 1937.

Apparentily rare in Iran.

Distribution in Iran : Fars.

General distribution: USSR (Kazakistan), Iran.

\section{Genus Therioplectes Zeller}

KEY TO THE SPECIES OF Therioplectes

Females

1. Last 3-4 tergites white haired; face with dark yellow

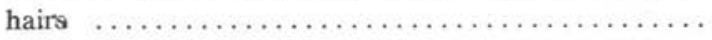
Th. albicaudus Olsufjev.

— Last 2-3 tergites rusty red; face with black hairs ... Th. carabaghensis

Portschinsky. 
The MALE of Th. albicaudus is not known.

Therioplectes albicaudus (Olsufjev), 1937.

Distribution in Iran: Caspian Sea littoral. This species is reported for the first time from Iran.

General distribution : Caspian Sea littoral of USSR (Lenkoran) and Iran.

Therioplectes carabaghensis (Portschinsky), 1877.

Distribution in Iran : Elburz Mountains, Gorgan Plain.

General distribution: USSR (Caucasus, Kopet-Dagh range, Turkmenia), Iran.

\section{Genus Tabanus Linnaeus}

KEY TO THE SPECIES OF THE GENUS Tabanus

\section{Females}

1. Eyes in life (or relaxed) without band $\ldots \ldots \ldots \ldots \ldots 2$

- Eyes in life (or relaxed) with one or several bands .. 28

2. Lower frontal callus connected by a prolongation with upper callus, which is keel - or spindle - shaped ..

- Lower frontal callus separated from upper callus (sometimes seemingly connected in rubbed specimens), which is usually square or an oval or heart shaped ....... 23

3. Large species : about $18-25 \mathrm{~mm} \ldots \ldots \ldots \ldots \ldots \ldots .4$

- Medium to small sized species : about 11,5-17 mm .. 14

4. Body entirely black, basal half of wing dark tinted .. T. anthrax Olsufjev.

- Body not entirely black, wings always hyaline ..... 5

5. Wing: $r_{4}$ with appendix; abdomen: silky dark grey

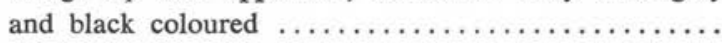

- Wing : $r_{4}$ rarely with an appendix, if so, abdomen brown yellow, not black-grey coloured .......... 7

6. Tergite I-III entirely grey, remaining tergites black .. T. shelkovnikovi shelkovnikovi Paramonov.

- Tergite I-III grey with black, median triangles; remaining tergites black $\ldots \ldots \ldots \ldots \ldots \ldots \ldots \ldots \ldots \ldots$.

7. Dorsum of abdomen with 2 sublateral longitudinal sharp and broad, whitish stripes, which are separated by a black median stripe $\ldots \ldots \ldots \ldots \ldots \ldots \ldots \ldots$.

- Dorsum of abdomen with a median row of pale trian-

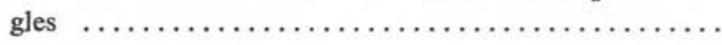

T. shelkovnikovi meridionalis Abbassian-Lintzen.

T. spectabilis Loew.

\section{8}

8. Triangles obtuse, truncate and not separated from each other: forming a contiguous, longitudinal, pale stripe

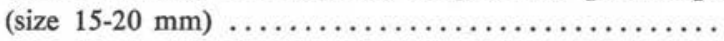

T. atropathenicus (*) Olsû́jev. 
- Triangles pointed, separated, not forming a contiguous, longitudinal stripe $\ldots \ldots \ldots \ldots \ldots \ldots \ldots \ldots \ldots \ldots \ldots \ldots$

9. Additional to median row of pale triangles dorsum of abdomen with 2 sublateral rows of pale oblique spots; upper callus spindle-shaped; size less than $20 \mathrm{~mm}$..

- Dorsum of abdomen without sublateral rows of pale oblique spots: upper callus keel-shaped; size $20 \mathrm{~mm}$

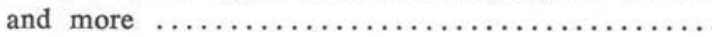

10. Frons very narrow (index 6-7); lower frontal callus an oblong rectangle, separated from sub-callus; $r_{4}$ often with an appendix; femora yellow (size 14-19 mm) ...

T. leclercqi Abbassian-Lintzen $(*)$.

- Frons not as narrow (index 4-5); lower frontal callus oval, touching subcallus; $r_{4}$ never with appendix; femora yellow or black $\ldots \ldots \ldots \ldots \ldots \ldots \ldots \ldots \ldots \ldots$

11. All femora yellow ............

T. polygonus Walker.

T. autumnalis brunnescens Szilady.

12. 1st. and 2nd. antennal segment brown-yellow; venter with a reddish-yellow median stripe; abdomen light reddish-yellow

T. tinctus Walker.

- 1st. and 2nd. antennal segment black; venter with a \pm sharp black stripe; abdomen blackish-brown or

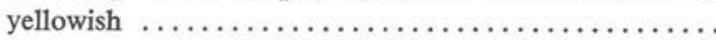

13. Tergite I-IV (or V) yellowish with exclusively whiteyellow hairs; median triangles very indistinct .......

- All tergites black brown with black hairs; median triangles sharp and distinct $\ldots \ldots \ldots \ldots \ldots \ldots \ldots \ldots \ldots$

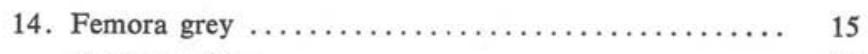

- Femora yellow $\ldots \ldots \ldots \ldots \ldots \ldots \ldots \ldots \ldots \ldots \ldots \ldots .20$

15. Dorsum of abdomen with an uninterrupted pale median stripe consisting of obtuse truncate triangles (size 15-

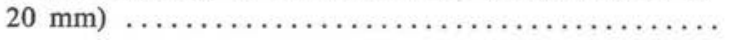

T. olsufjevi Hauser.

T. capito Olsufjev.

\section{T. atropathenicus \\ Olsufjev. (*).}

- Dorsum of abdomen without such a stripe, but with a medium row of distinct triangles and 2 rows of subla-

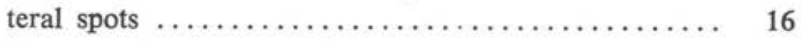

16. Venter entirely grey-black $\ldots \ldots \ldots \ldots \ldots \ldots \ldots \ldots . \quad 17$

- Venter at least yellow-brown in basal half ........ 19

17. Rim of occiput relatively broad and with a fringe of long, forwardly bent hairs

T. miki australis Hauser.

(*) Because of variation in size this species had to be keyed twice. 
- Rim of occiput narrow and with a fringe of short, erect

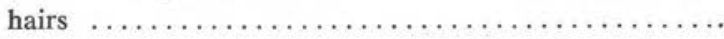

18. Frons narrow (index 5-6); lower frontal callus an oblong rectangle, brownish, subdued

T. regularis Jaennicke.

T. indrae Hauser.

19. Dorsum of abdomen grey-black with a moderately large, reddish-brown lateral spot on tergite II and III (rarely on tergite I-IV); rim of occiput with a fringe of long, forwardly bent hairs $\ldots \ldots \ldots \ldots \ldots \ldots \ldots \ldots \ldots$

- Dorsum of abdomen yellow ; rim of occiput with short

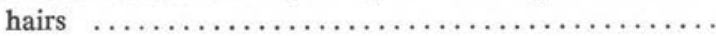

20. Frons very narrow (index 6-7); lower frontal callus an oblong rectangle ; $\mathrm{r}_{4}$ often with appendix; 3rd. antennal segment: annulate portion considerably shorter than plate ; larger species : $14-19 \mathrm{~mm} . \ldots \ldots \ldots \ldots$.

T. leclercqi Abbassian-Lintzen $(*)$.

- Frons broader (index 5-6) ; lower frontal callus a longish oval or quadrat-shaped; $\mathrm{r}_{4}$ without appendix; 3rd. antennal segment: annulate portion about as long as plate ; smaller species: $11,5-15 \mathrm{~mm} \ldots \ldots \ldots \ldots$.

21. Dorsum of abdomen dark grey, venter pinkish grey ...

T. miki miki Brauer

T. semenovi Olsufjev.

21

T. assuetus Hauser.

22

T. pallidipes Austen.

T. laetitinctus Becker.

T.? rupinae Austen.

T. mofidii Leclercq. 
- Middle callus broad oval (ab. two third of frontal width); eyes dark green in life; dorsum of abdomen blackish-grey ; hind tarsi with many black hairs, therefore blackish in appearance ; larger species : 11-15 mm

26. Antennae reddish-yellow; venter brown yellow ...... and Samedov.

T. mofidii atrofemoratus, Abbassian-Lintzen.

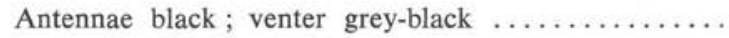

27. Eyes distinctly hairy under a hand lens; sides of frons parallel; subcallus lacking band across base of

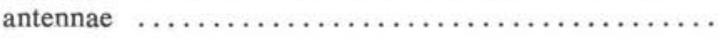

- Eyes bare; sides of frons divergent towards vertex; subcallus with a black-brown band across base of

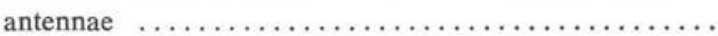

28. Eyes in life (or relaxed) with one band ...........

- Eyes in life (or relaxed) with more than one band:

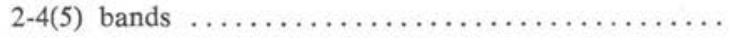

29. Lower callus connected by a prolongation with upper callus, which is spindle shaped $\ldots \ldots \ldots \ldots \ldots \ldots \ldots \ldots$

- Lower callus separated from upper callus, which is usually square or an oval or heart shaped ..........

30. Femora yellow

T. oppugnator Austen.

$T$. cordiger Meigen.

29

T. mouchaei Leclercq.

31. Lower callus touching eye margins; dorsum of abdomen with anteriorly broadened triangles, which form a pale contiguous median stripe. $\ldots \ldots \ldots \ldots \ldots \ldots$.

- Lower callus separated from eye marging; dorsum of abdomen with well separated pale median triangles, which do not form a contiguous stripe .............

T. canipalpis Bigot.

32. Dorsum of abdomen entirely grey-black, or laterally

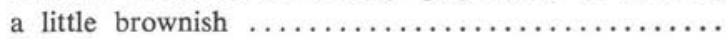

- Dorsum of abdomen with tergites I-V or I-VI laterally yellowish $\ldots \ldots \ldots \ldots \ldots \ldots \ldots \ldots \ldots \ldots \ldots \ldots$

33. Body olive-grey coloured; lower callus light brown to yellowish and in a distance from subcallus, the latter without a band across base of antennae; eyes hairy

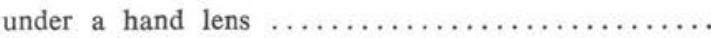

T. bromius Linnaeus.

T. bromius flavofemoratus Strobl.

T. bifarius Loew (*).

- Body black and grey coloured; lower callus black and in connection with subcallus, the latter with a blackish band across base of antennae; eyes bare ............

(*) Because of variation in the number of eye-bands this species had to be keyed twice. 
34. Frons moderately broad: index 3,25 to 3,5 ; sides slightly divergent toward vertex $\ldots \ldots \ldots \ldots \ldots \ldots \ldots$

T. unifasciatus Loew.

35

T. Leleani Austen.

T. leleani pallidus Olsufjev.

T. tergestinus Egger.

38

40

T. quatuornotatus Meigen.

T. bifarius Loew.

T. glaucopis Meigen.

41. Femora and abdomen pale brown-yellow, setae on basicosta often yellow $\ldots \ldots \ldots \ldots \ldots \ldots \ldots \ldots \ldots$

- Femora blackish; abdomen dark brown; setae on basicosta black

\section{.}

42. Eyes with 2 sharply defined bands in life (or relaxed); head considerably broad; $r_{4}$ with an appendix ......

- Eyes with more than 2 sharply defined bands in life (or relaxed); head not considerably broad; $\mathrm{r}_{4}$ with or without appendix

\section{T. kermani \\ Abbassian-Lintzen.}

T. bactrianus Olsufjev.

T. zimini Olsufjev.

43. Eyes with 3 purple bands in life (or relaxed) ....... 44 
- Eyes with 4 bands in life (or relaxed): one purple band above and one below and two deep blue bands in the

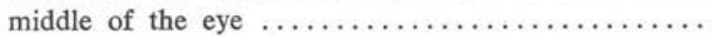

44. Wings : $r_{4}$ without appendix ; dorsum of abdomen with 3 contiguous, longitudinal pale stripes .............

T. gratus Loew.

- Wings: $r_{4}$ with an appendix; dorsum of abdomen without contiguous stripes $\ldots \ldots \ldots \ldots \ldots \ldots \ldots \ldots$

45. Frons narrow (index 4 to 5); subcallus high, flat and without a band across base of antennae ...........

T. accipiter Szilady.

- Frons broad (index about 2,5) ; subcallus low, considerably inflated and with a dark band across base of

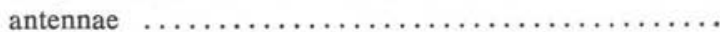

46. Wings light brown with a conspicuous, dark brown stigma ; dorsum of abdomen, venter and 1st. antennal

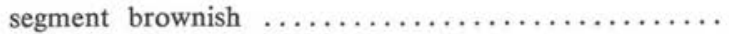

T. ansarii ansarii

Abbassian-Lintzen.

- Wings hyaline or greyish; stigma yellow and inconspicuous; dorsum of abdomen and venter greyish to blackish; 1st. antennal segment black .............

47. Wings: veins strongly contrasting against wing membran: femora brownish

T. ansarii nigrinervis,

Abbassian-Lintzen.

- Wings : veins not remarkably contrasting; femora

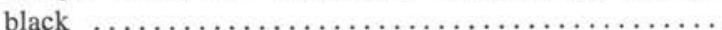

T. ansarii gedrosiae

Abbassian-Lintzen.

48. Wings : $r_{4}$ without appendix $\ldots \ldots \ldots \ldots \ldots \ldots \ldots \ldots$

T. mistshenkoi Olsufjev.

49

49. Femora yellow; lower frontal callus brown-yellow; crossveins darker coloured than longitudinal veins,

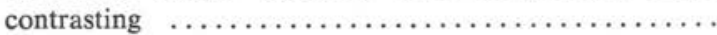

T. sufis Jaennicke.

- Femora black; lower frontal callus black; crossveins not darker coloured than longitudinal veins, not

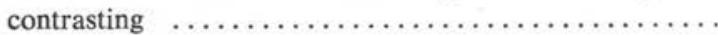

T. sabuletorum Loew.

\section{MaLes}

The males of $T$. shelkovnikovi meridionalis, T. atropathenicus, T. miki australis, $T$. semenovi, $T$. laetitinctus, $T$. indrae, $T$. oppugnator, $T$. sordes, $T$. mofidii atrofemoratus, T. mouchaei, T. kermani, T. bactrianus, $T$. ansarii nigrinervis and $T$. ansarii gedrosiae are not known and are not keyed. T. assuetus is also excluded. The following key to the males is therefore incomplete and is to be regarded as a preliminary attempt.

1. Large species: about $17-24 \mathrm{~mm} \ldots \ldots \ldots \ldots \ldots \ldots .2$

- Medium to small sized species : about 10-17 $\mathrm{mm} \ldots 10$ 
2. Body entirely black; basal half of wings dark tinted

- Body not entirely black; wings always hyaline ......

3. Wings with an appendix to $r_{4}$; abdomen silky dark grey and black coloured $\ldots \ldots \ldots \ldots \ldots \ldots \ldots \ldots \ldots$

- Wings rarely with an appendix to $r_{4}$, if so, then abdomen brown yellow, not grey-black coloured .........

4. Dorsum of abdomen with 2 sublateral longitudinal, sharp and wide, whitish stripes, which are separated by a black median stripe $\ldots \ldots \ldots \ldots \ldots \ldots \ldots$.

- Dorsum of abdomen with a median row of pale trian-

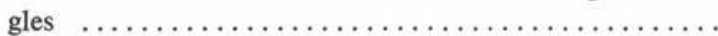

5. Additional to median row of pale triangles dorsum of abdomen with sublateral rows of pale oblique spots ; size of body less than $20 \mathrm{~mm} \ldots \ldots \ldots \ldots \ldots$.

- Dorsum of abdomen without sublateral rows of pale oblique spots; size of body usually $20 \mathrm{~mm}$ and more.

6. All or at least fore femora black

- All femora reddish-yellow

7. 3rd. antennal segment: plate about as long as annulate portion; ocellar tubercle very narrow and long; large facets appr. 4 times as large as small facets; ground colour of scutellum reddish-brown; no appen-

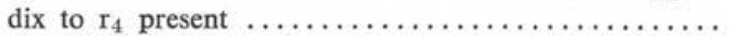

- 3rd. antennal segment: plate about twice as long as annulate portion; ocellar tubercle broader and shorter; large facets appr. 6 times as large as small facets; ground colour of scutellum blackish; $\mathrm{r}_{4}$ often with

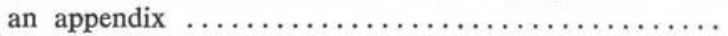

6. Large facets sharply differentiated from small facets; dorsum of abdomen brown $\ldots \ldots \ldots \ldots \ldots \ldots \ldots$.

8. Large facets sharply differentiated from small facets; facets; dorsum of abdomen brick red-yellow or plain

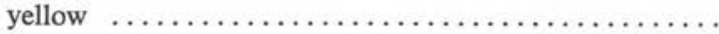

9. Tergite I-IV (or V) plain yellow with exclusively white-yellow hairs $\ldots \ldots \ldots \ldots \ldots \ldots \ldots \ldots \ldots \ldots$

- Tergite I-IV (or V) brick red-yellow with predomi-

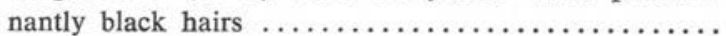

10. Rim of occiput with short erect hairs $\ldots \ldots \ldots \ldots .11$

- Rim of occiput with long recumbent hairs ........ 22

11. Head enlarged, \pm hemispheric; small facets sharply differentiated from large ones $\ldots \ldots \ldots \ldots \ldots \ldots \ldots$
T. anthrax, Ols. 3

T. shelkovnikovi Par.

4

T. spectabilis Lw.

6

8

T. autumnalis brunnescens Szil.

7

T. polygonus Walk.

T. leclercqi Abb.-L. (*).

T. capito Ols.

9

$T$. olsufjevi Haus.

T. tinctus Walk.

(*) Because of variation in size this species had to be keyed twice. 
- Head not enlarged : not larger than in $\$$; small facets either sharply differentiated from large ones or all facets of nearly the same size $\ldots \ldots \ldots \ldots \ldots \ldots \ldots$.

12. Wings with an appendix to $r_{4} \ldots \ldots \ldots \ldots \ldots \ldots \ldots \ldots$

- Wings without an appendix to $r_{4} \ldots \ldots \ldots \ldots \ldots \ldots .14$

13. 3rd. antennal segment: plate about as long as annulate portion; terminal segment of palpi short oval: less than twice as long as thick; femora usually partly or wholly greyish; pale sublateral oblique spots reaching anterior margins of tergites $\ldots \ldots \ldots \ldots \ldots \ldots$

- 3rd. antennal segment: plate about twice as long as annulate portion ; terminal segment of palpi long oval : ab. 2,5 times as long as thick; femora completely yellow ; pale sublateral oblique spots not reaching anterior margins of tergites $\ldots \ldots \ldots \ldots \ldots \ldots \ldots \ldots \ldots \ldots$

14. Small facets with 2 bands in life (or relaxed); dorsum of abdomen with 3 contiguous, pale, longitudinal stripes ; small species

T. rupinae Aust.

T. leclercqi Abb.-L.

T. gratus Lw.

15

16

18

16. A dark parafacial band across base of antennae ......

T. leleani Aust. (*).

17

17. Palpi long oval, often pointed at apex $\ldots \ldots \ldots \ldots \ldots$

T. regularis Jaen.

T. canipalpis Big.

18. In life (or relaxed) eye-band is appr. semi-circular, it encircles area of large facets from three sides: running along the border of small facets it begins at lateral margin of frontal triangle and extends all the way back upwards to ocellar tubercle $\ldots \ldots \ldots \ldots \ldots \ldots$

- In life (or relaxed) eye-band is not semicircular, but $\mathrm{a} \pm$ straight line: it runs along the upper border of small facets, tapers laterally and disappears at lower externe angle of large facets $\ldots \ldots \ldots \ldots \ldots \ldots \ldots$

19. Eyes with one band in life (or relaxed) ......... 20

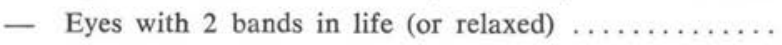

20. Dorsum of abdomen entirely grey-black or laterally

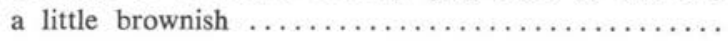

- Dorsum of abdomen with tergite I-V or I-VI laterally

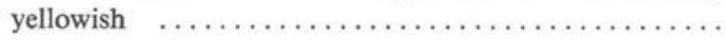

T. mofidii Lecl.

T. pallidipes Aust.

T. bromius bromius $\mathrm{L}$.

T. bromius flavofemoratus Str.

(*) Because of variation in length of occipital hairs this species had to be keyed twice.

Ann. de Parasitologie humaine et comparée (Paris), t. 39, 1964, $\mathrm{n}^{\circ} 3$ 
21. Eye facets of nearly the same size; wings without an

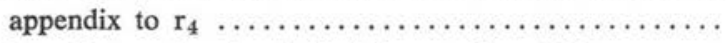

- Eye facets sharply divided in small and large ones; wings with an appendix to $r_{4} \ldots \ldots \ldots \ldots \ldots \ldots$

T. tergestinus Egg.

T. accipiter Szil.

22. Head enlarged, \pm hemispheric; small facets sharply differentiated from large ones $\ldots \ldots \ldots \ldots \ldots \ldots \ldots$.

- Head not enlarged, not larger than in $\%$; small facets either sharply differentiated from large ones or all facets of nearly the same size $\ldots \ldots \ldots \ldots \ldots \ldots \ldots \ldots$

23. Upper part of frontal triangle bare and shining ......

- Frontal triangle completely covered by tomentum,

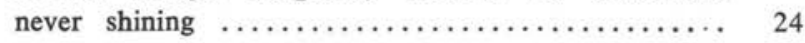

24. Wings without an appendix to $r_{4} \ldots \ldots \ldots \ldots \ldots \ldots 25$

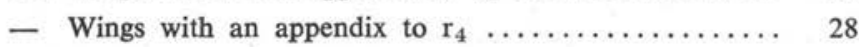

25. Small facets with 3 bands $\ldots \ldots \ldots \ldots \ldots \ldots \ldots \ldots \ldots \ldots \ldots \ldots \ldots \ldots$. mistshenkoi Ols.

- Small facets with one or without band ........... 26

26. No dark parafacial band across base of antennae; palpi long oval; head medium sized .............

- A dark parafacial band across base of antennae; palpi globular, thick; head very enlarged: nearly hemisphe-

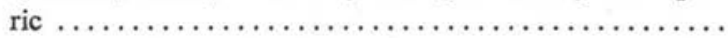

27. Rim of occiput with very long hairs, which reach considerably forwards over the eye surface; small facets without or with an indistinct band in life (or relaxed)

- Rim of occiput with shorter hairs, which reach only a little forwards over eye surface; small facets with a sharp, distinct band in life $\ldots \ldots \ldots \ldots \ldots \ldots \ldots \ldots$.

28. Femora yellow; crossveins darker coloured than longitudinal veins, contrasting $\ldots \ldots \ldots \ldots \ldots \ldots \ldots \ldots$

- Femora black; crossveins darker coloured than longitudinal veins, not contrasting $\ldots \ldots \ldots \ldots \ldots \ldots$

29. Eyes hairy under a hand lens $\ldots \ldots \ldots \ldots \ldots \ldots \ldots .30$

- Eyes bare or at least microscopically hairy ........ 31

30. Palpi short oval, rounded at apex ; dorsum of abdomen

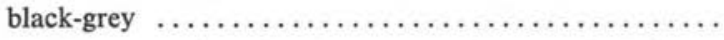

- Palpi long oval, pointed at apex; dorsum of abdomen

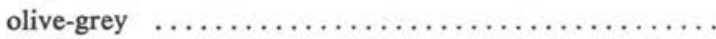

31. Wings without an appendix to $r_{4}$; eyes with one band

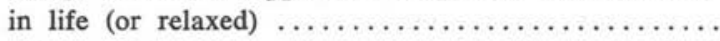

- Wings with an appendix to $r_{4}$; eyes with two bands in

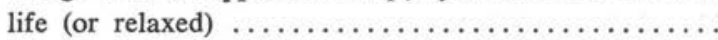

T. miki $\mathrm{Br}$.

T. cordiger $\mathrm{Mg}$.

T. leleani Aust.

T. sufis Jaen.

T. sabuletorum Lw. 30

T. quatuornotatus $\mathrm{Mg}$.

T. bifarius Lw.

T. unifasciatus Lw.

32. Small eye facets sharply differentiated from large ones; rim of occiput very broad and with very long, white hairs; head very broad $\ldots \ldots \ldots \ldots \ldots \ldots \ldots \ldots \ldots$.

T. zimini Ols. 
- Small facets growing gradually larger ; rim of occiput narrow and with black, shorter hairs; head normally

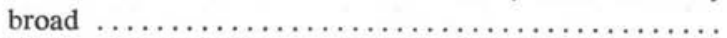

T. ansarii Abb.-L.

Tabanus anthrax Olsufjev, 1937.

Distribution in Iran : Elburz Mountains.

General distribution: USSR (Transcaucasia), Iran.

Tabanus shelkovnikovi shelkovnikovi Paramonov, 1933, syn.: T. bouvieri Philip, 1959.

According to specimens kindly sent by Prof. Olsufjev, this species and the following subspecies are very nearly related to $T$. grandis Szil. from Asia Minor and Central Asia and T. schiva Moucha and Chvala from Central Asia.

Distribution in Iran : Elburz Mountains.

General distribution: USSR (Transcaucasia), Iran.

Tabanus shelkovnikovi meridionalis Abbassian-Lintzen, 1960.

Distribution in Iran : Kerman province (S.E. spurs of Zagros range).

General distribution : Iran.

Tabanus spectabilis Loew, 1858.

This species is more common in dry semidesert-like surroundings. According to our experience it attacks exclusively the dorsum of animals and is suspicious and not easy to catch. Alt. : 800-2 $400 \mathrm{~m}$.

Distribution in Iran : Fars, Kerman province, Khorassan, Elburz Mountains, Tehran, Ghazwin, Azerbaijan, Isfahan, Kurdistan.

General distribution: Southern Europe, North Africa, Iraq, Asia Minor, USSR (Ukraine, Caucasus, Central Asia), Iran.

Tabanus atropathenicus Olsufjev, 1937.

Smaller specimens of this species from Fars have been identified and reported erroneously as $T$. taeniola form variatus Walk. by the writer (Abbassian-Lintzen, $1960 \mathrm{~B})$. In the following year the record of normal sized specimens of $T$. atropathenicus (identification confirmed by Prof. Olsufjev) from Jiroft (Kerman province) and comparison of Iranian material with African specimens of taeniola kindly sent by Mr. H. Oldroyd, made our mistake obvious. This species has been taken at $800 \mathrm{~m}$ and $1800 \mathrm{~m}$ alt.

Distribution in Iran : Fars, Kerman province (S.E. spurs of Zagros range).

General distribution : USSR (Transcaucasia), Iran.

Tabanus leclercqi Abbassian-Lintzen, 1960.

Distribution in Iran : Baluchistan, Kerman province, Fars, Khuzistan. Alt. : 420$1800 \mathrm{~m}$.

General distribution: Iran.

Tabanus polygonus Walker, 1854.

Distribution in Iran : Khuzistan Plain.

General distribution: Iraq, Iran. 
Tabanus autumnalis brunnescens Szilady, 1914.

This species is very variable in colouration. Southern specimens (Fars, Kerman province, Baluchistan) are very light in colour and resemble polygonus, but have only the middle and hind femora reddish yellow. The colouration grows gradually darker till we find among the Caspian Sea coast population specimens which are almost identical with the nominal form from Europe. At certain days in summer this species is extremely abundant at the Caspian Sea littoral : during the morning of 20th August 1962 we observed hundreds of specimens (mostly $+\uparrow)$ flying with force against the white-washed walls of the house, falling to the ground, where most of the flies remained for a while, then obviously recovering and flying away. T. autumnalis brunnescens is the most common horsefly of the non-forested plains of the Caspian Sea coast and is often found in rooms and behind window panes. Recorded altitude in Iran : sea level to $2400 \mathrm{~m}$. The species has also been recorded in light-and window-traps at the Caspian Sea coast. It is rare at saline breeding places.

Distribution in Iran : Except Elburz Mountains and Khuzistan Plain almost ubiquitous in Iran : Fars, Kerman province, Baluchistan, Kavir Desert, Khorassan, Gorgan Plain, Caspian Sea littoral, Azerbaijan, Isfahan, Kurdistan.

General distribution: Southern Europe, North Africa, Palestine, Syria, Asia Minor, Afghanistan, Iraq, USSR (Crimea, Caucasus, Western Siberia, Central Asia), Iran.

Tabanus tinctus Walker, 1850, syn.: T. intermedius Egger, 1859; T. eggeri Schiner, $1868 ; T$. polyzonatus Bigot, 1898.

We recorded 5 우 of this species, whose occurrence in Iran has been questioned (Olsufjev, 1937, p. 404), in a well vegetated valley near Kermanshah, Kurdistan (VIII.63., car). Ricardo reported 2 우 from Sisten ( $\ll$ Seistan »), Persia (Ricardo, 1911, p. 249).

Distribution in Iran : Sistan, Kurdistan.

General distribution: Central and Southern Europe, North Africa, Asia Minor, Palestine, USSR (Caucasus), Iran.

Tabanus olsufjevi Hauser, 1960.

Distribution in Iran : Elburz Mountains (1 $800 \mathrm{~m}$ ). First record in Iran.

General distribution: USSR (Transcaucasia), Iran.

Tabanus capito Olsufjev, 1937.

Distribution in Iran : Fars, Elburz Mountains (alt. 1900-2 030 m).

General distribution: USSR (Transcaucasia), Iran.

Tabanus miki miki Brauer, 1880.

Distribution in Iran : Elburz Mountains, Azerbaijan, Khorassan, Fars. Alt. : 1000 $2100 \mathrm{~m}$.

General distribution: Central Europe, Balkan, USSR (central and southern part of European USSR, Crimea, Caucasus, Western Siberia), Asia Minor, Iran.

Tabanus miki australis Hauser, 1960. 
This subspecies of miki has been reported as $T$. miki $\gtreqless m i k i$ niger from the Elburz Mountains (Abbassian-Lintzen, 1960 C). Prof. Olsufjev identified a specimen of the respective series as miki australis Haus.

Distribution in Iran : Elburz Mountains.

General distribution: USSR (Transcaucasia), Iran.

Tabanus regularis Jaennicke, 1866.

Distribution in Iran: Baluchistan, Kerman province, Fars, Khuzistan, Elburz Mountains, Kurdistan (alt. : 100-2 400 m).

General distribution: Southern Europe, North Africa, Asia Minor, Palestine, Iraq, USSR (Transcaucasia), Iran.

Tabanus indrae Hauser, 1960.

This species is related to $T$. armeniacus $\mathrm{Kr}$., but is easily to distinguish from the latter. Till recently neither the description nor any identified specimens of this species (and the above miki australis) have been available to the writer, the species had therefore been reported as T. armeniacus Kr. (Abassian-Lintzen, $1960 \mathrm{C}$, 1961). Thanks to the kindness of Dr. Sh. M. Djafarov, Baku, and Prof. Olsufjev, we received the description as well as identified specimens of $T$. indrae and $T$. armeniacus and are now able to correct the mistake in determination.

Distribution in Iran : Elburz Mountains, Kerman province (S.E. spurs of Zagros range).

General distribution : USSR (Caucasus, Crimea), Iran.

Tabanus semenovi Olsufjev, 1937.

Distribution in Iran : Kerman province (S.E. spurs of Zagros range).

General distribution : USSR (Central Asia), Afghanistan, Iran.

Tabanus assuetus Hauser, 1960.

Very well to distinguish from laetitinctus and other related species. First record in Iran.

Distribution in Iran : Ghazwin (1 $300 \mathrm{~m}$ alt.).

General distribution : USSR (Transcaucasia), Iraq, Iran.

Tabanus pallidipes Austen, 1919.

The correct identification of $T$. pallidipes was difficult as noted previously (Abbassian-Lintzen, 1961 , p. 143 and 1963 , p. 84) due to the lack of good criteria between the present species and the following $T$. laetitinctus.

Distribution in Iran : Khuzistan Plain.

General distribution : Palestine, Syria, Iraq, Iran.

Tabanus laetitinctus Becker, 1912.

Distribution in Iran : Fars, Baluchistan, Kerman province, Kavir Desert, Khorassan, Elburz Mountains (alt. : $550 \mathrm{~m}$ to $2100 \mathrm{~m}$ ).

General distribution: USSR (Central Asia), Iran, Afghanistan, Iraq.

Tabanus? rupinae Austen, 1919. 
The problematic taxonomical status of $T$. ? rupinae from Iran has been discussed recently (Abbassian-Lintzen, 1964).

Distribution in Iran : Baluchistan, Kerman province, Fars, Khuzistan, Azerbaijan, northern border of Kavir Desert (Damghan). Alt. : 200-1 800 m.

Tabanus mofidii mofidii Leclercq, 1960.

Distribution in Iran : Baluchistan, Kerman province, Fars.

General distribution : Iran.

Tabanus mofidii atrofemoratus Abbassian-Lintzen, 1964.

Distribution in Iran : Azerbaijan.

General distribution : Iran.

Tabanus sordes Bogachev and Samedov, 1949.

A distinct species belonging to the cordiger group. First record in Iran.

Distribution in Iran : N. Khorassan, Elburz Mountains, alt. : $1300 \mathrm{~m}$ and $1800 \mathrm{~m}$.

General distribution: USSR (Caucasus), Iran.

Tabanus oppugnator Austen, 1925.

Distribution in Iran : Luristan.

General distribution : Asia Minor, Iran.

Tabanus cordiger Meigen, 1820.

Distribution in Iran : Elburz Mountains.

General distribution: Central and Southern Europe, North Africa, Asia Minor, Syria, USSR (central and southern part of European USSR, Caucasus), Iran, Japan, Central China, Korea.

Tabanus mouchaei Leclercq, 1962.

Up to the present we did not record this species.

Distribution in Iran : Elburz Mountains.

General distribution : Iran.

Tabanus canipalpis Bigot, 1892.

Distribution in Iran : Baluchistan, Kerman province.

General distribution: Iran.

Tabanus bromius bromius Linnaeus, 1761.

Common in well vegetated environments with a cooler climate except Caspian Sea littoral.

Distribution in Iran: Kerman province, Fars, Khuzistan, Kurdistan, Azerbaijan, Elburz Mountains, Tehran, N. and S. Khorassan. Alt. : 450-2 $400 \mathrm{~m}$.

General distribution: Whole Europe, N. Africa, Asia Minor, Palestine, Afghanistan, USSR (W. Siberia, Caucasus, Central Asia), Iran.

Tabanus bromius flavofemoratus Strobl, 1908.

Distribution in Iran: Tehran (very abundant at north-western border of Kavir Desert), Elburz Mountains, Khorassan, Azerbaijan, Isfahan, Khuzistan, Fars. Alt. : 450$2000 \mathrm{~m}$. 
General distribution: Southern Europe, North Africa, USSR (Caucasus, Central Asia), Iran.

Tabanus bifarius Loew, 1858.

Apparently restricted to a more humid climate and a better vegetated landscape (alt. : $1000-1300 \mathrm{~m}$ ). In this species the number of eye bands is not constant, but changing from one to three.

Distribution in Iran : Mountainous part of Caspian Sea coast, Kurdistan.

General distribution: Southern and Central Europe, North Africa, Asia Minor, USSR (Ukraine, Crimea, Caucasus), Iran.

Tabanus unifasciatus Loew, 1858.

Distribution in Iran : Khorassan, Tehran, Elburz Mountains, Azerbaijan, Kurdistan, Fars, Kerman province, Baluchistan.

General distribution: Central and Southern Europe, North Africa, Asia Minor, USSR (S. Ukraine, Crimea, Caucasus), Iran.

Tabanus leleani Austen, 1919.

Like $T$. autumnalis brunnescens almost ubiquitous in Iran except the Caspian Sea coast, the Khuzistan Plain and the Elburz Mountains. Recorded at elevations from $300 \mathrm{~m}$ to $1800 \mathrm{~m}$.

Distribution in Iran: Baluchistan, Kerman province, Sistan, Fars, Khuzistan (hills), Kurdistan, Azerbaijan, Tehran, Gorgan Plain, Isfahan, N. and S. Khorassan.

General distribution: Southern Europe, North Africa, Cyprus, Palestine, Syria, Iraq, Asia Minor, Afghanistan, USSR (Caucasus, Central Asia), Punjab, Mongolia, Iran.

Tabanus leleani pallidus Olsufjev, 1937.

Distribution in Iran : Khorassan (northern border of Kavir Desert).

General distribution: USSR (Turkmenia), Iran.

Tabanus tergestinus Egger, 1859.

Apparently rare, first record in Iran.

Distribution in Iran : Caspian Sea littoral.

General distribution: Central and Southern Europe, USSR (S.W. Ukraine, Caucasus), Iran.

Tabanus quatuornotatus Meigen, 1820.

Distribution in Iran : Fars, Kerman province, Elburz Mountains (2900 m), Kurdistan.

General distribution: Central and Southern Europe, USSR (Caucasus), Iran.

Tabanus glaucopis Meigen, 1820.

Distribution in Iran : Fars (rare).

General distribution: Central and Southern Europe, Asia Minor, USSR (central and southern part of European USSR, Caucasus, Siberia till Transbaikalia), Iran.

Tabanus kermani Abbassian-Lintzen, 1960.

Distribution in Iran : Kerman province.

General distribution : Iran. 
Tabanus bactrianus Olsufjev, 1937.

Described first as a subspecies of lunatus. The present writer reported the species provisionally as a variation of $T$. kermani (Abbassian-Lintzen, 1962, p. 446). Comparison with material of $T$. bactrianus kindly forwarded by Prof. Olsufjev showed that the species from Fars is identical with bactrianus, which is now reported for the first time from Iran. Very abundant early in June at higher elevations (1 600-1 $800 \mathrm{~m}$ ).

Distribution in Iran : Fars.

General distribution: USSR (Central Asia), Afghanistan, Iran.

Tabanus zimini Olsufjev, 1937.

Obviously a halophile species and at certain places (Sabsevar; Lake Maharlu) sometimes rather numerous.

Distribution in Iran: N. Khorassan, Baluchistan, Fars, Azerbaijan. Alt. : 900$1600 \mathrm{~m}$.

General distribution : USSR (S.W. part of Caspian Sea littoral, Central Asia), Iran, Iraq.

Tabanus gratus Loew, 1858.

Distribution in Iran: Baluchistan, Kerman province (uncommon). Alt. : 350$800 \mathrm{~m}$.

General distribution: Entire Ethiopan Region except equatorial forest belt, Egypt, Iran (not recorded in Palestine according to Prof. O. Theodor, pers. com.).

Tabanus accipiter Szilady, 1923.

Distribution in Iran : Fars, Kerman province. Alt. : 550-1 350 m.

General distribution: USSR (Central Asia), Iran.

Tabanus ansarii ansarii Abbassian-Lintzen, 1960.

Distribution in Iran : Fars, Khuzistan. Alt. : 380-550 m.

General distribution : Iran.

Tabanus ansarii nigrinervis Abbassian-Lintzen, 1961.

Distribution in Iran : Baluchistan. Alt. : $1200 \mathrm{~m}$.

General distribution: Iran.

Tabanus ansarii gedrosiae Abassian-Lintzen, 1961.

Distribution in Iran : Baluchistan, Fars. Alt. : $1200-1500$ m.

General distribution : Iran.

Tabanus mistshenkoi Olsufjev, 1937.

Widespread in southern Iran.

Distribution in Iran : Baluchistan, Fars, Khuzistan. Alt. : 100-1 750 m.

General distribution: USSR (Central Asia), Iran.

Tabanus sufis Jaennicke, 1867.

Distribution in Iran : Baluchistan, Kerman province, Fars, Khuzistan. Alt. : 100$1800 \mathrm{~m}$.

General distribution: Ethiopian Region (semi-desert belts S.E. of Sahara), Egypt, Palestine, Iraq, Iran, Punjab. 
Tabanus sabuletorum Loew, 1874.

Obviously a halophile species, not common.

Distribution in Iran : northern and northeastern Khorassan, (northern margin of Kavir Desert and at boundary river Hari-rud), Baluchistan, Fars, Azerbaijan. Alt. : ab. 500-1 $600 \mathrm{~m}$.

General distribution: USSR (S. Ukraine, Crimea, Caucasus, Central Asia), Mongolia, Iran.

\section{NOTES ON THE BIONOMICS OF TABANIDAE IN IRAN}

Very little is known about this subject. It appears, that in most parts of Iran Tabanidae are much less frequent as individuals than e.g. in Europe or Siberia. This is mainly due to climatic conditions. Except the Caspian Sea littoral, Iran is a very arid country with a low annual rainfall, relatively few natural waterbodies and an extremely dry soil, which is entirely unsuitable to the larval life of horseflies. The latter stages are therefore exclusively members of a biocoenosis provided by permanent water or the humid soil of banks. Swamps and slow shallow wide rivers are apparently the best breeding grounds. At such places one can observe at certain times of the season a great number of Tabanidae (appr. 60-80 specimen in one hour) attacking a «bait * animal. These periods seem to be roughly simultaneous with the wheat harvest, which date depends chiefly on geographical latitude and elevation of the respective locality. For collecting females we are always in need of an animal as bait, since only exceptionally we were able to catch tabanids with a net from vegetation or rocks, walls, etc. During the past 5 years a considerable number of brachycerous flies other than Tabanidae have been collected with a net. The proportion of these to horseflies caught in this way may be 100: 1 or less. More specimens of Tabanidae ( $\$+$ and $00^{\circ}$ ) can be obtained in a closed car with an open window standing under the hot sun ; the liking of tabanids to enter such a vehicle is well known.

Occasionally Tabanidae were observed to rest in the shadow of tree branches and bushes, in grass tufts, under low bridges, in a cave $\left(\delta \sigma^{*}\right.$ of an unidentified species in large numbers, S. Iran) or to sit in the sunshine on hot rocks, walls, car hoods and iron tools (in the latter case numerous specimens of At. pulchellus, Karun river), on tree trunks and in the early morning in a suburb of Tehran on lamp-posts ( $T$. bromius flavofemoratus, large quantities).

As said above, the presence of water is necessary for the development of immature stages of Tabanidae, and since the flies apparently do not fly far away from their breeding places like e.g. many Simuliidae do, horseflies are only to be found in the vicinity of springs, lakes, marshes, rivers, etc. In dry, waterless steppes and semi-deserts we observed many kinds of brachycerous flies but no tabanids. Ghanats, artificial watercourses common in Iran with their limited aquatic life and cool water, do not appear to provide good living conditions for larvae, but such species like $T$. autumnalis brunnescens, $T$. leleani, $T$. spectabilis and $T$. unifasciatus have been recorded at places where they could only have bred in « ghanat-creeks ». 
The months, during which Tabanidae are on the wing, differ of course according to latitude, altitude and kind of species. The few observations, which we could make in this respect, show the earliest record of a tabanid fly in Iran to be April 2nd. $27^{\circ} 15^{\prime}$ N., $800 \mathrm{~m}, T$. leleani). The latest records were made on November 16th. (lat. $28^{\circ} 40^{\prime}$ N., $700 \mathrm{~m}, T$. leleani) and October 12th. (lat. $36^{\circ} 30^{\prime}$ N., $900 \mathrm{~m}$., T. leleani).

Not all species of Iranian Tabanidae exhibit the same behaviour in attacking an animal to suck blood. This has been reported by Efflatoun Bey (1930), Bouvier (1945) and other authors. We made the observation, that species of Haematopota select almost exclusively the face and side of neck of an animal for feeding. Nemorius species show the same preference, but settle also on the flanks and the side of the belly. Species of these genera as well as of Chrysops and Atylotus approach their victims soundless and alight in a very unconspicuous way, so that the beast is not afraid of them. In contrast large and striking species of the genus Tabanus, like spectabilis and capito, attack with a typical loud buzz, of which the beasts are mostly very well aware. The more sensitive and healthy of them try to frighten away the fly by kicking and rearing, in which they often succeed. But sometimes apparently the same fly returns again and again till finally the blood-sucker defeats the weary animal. It may be for this reason, that the larger Tabanus species of bovinus (Bouvier, 1945), spectabilis and capito do settle on the dorsum of their victims. Dark coloured animals with smooth, fine and adpressed hairs are prefered to those with lighter coloured and/or unkept, rough hair. The author observed that except horses, donkeys, camels, buffaloes and cattle dogs are also bitten by tabanids (Chrysops). Humans are attacked readily by species of the latter genus, Haematopota and Nemorius and to a lesser degree by the smaller species of Tabanus (mofidii, ansarii, sabuletorum, etc.). I have been bitten sometimes by Tabanidae on the bare hands, arms and legs. The bite never caused more serious effects than that of a mosquito. My male colleagues are often bitten on the hairless parts of the head, especially while bathing in rivers. Tabanidae appear to prefer the wet human skin to the dry one. At favourable breeding places, where no animal was available as bait, we made use of this peculiarity by collecting horseflies from the moistened and to the sun exposed human skin of a volunteer.

Generally Tabanidae feed predominantly during the warmer hours of the day in bright sunlight. But in South Iran during the great heat horseflies seem to rest most of the day and attack for feeding practically only in the early morning and late afternoon. The biting activity of Haematopota species is increased by cloudiness or during a slight drizzle of rain. Observations about the preference of several species to certain kinds of breeding places have been reported previously from Transcaucasia and Iran (Djafarov, 1960, Abbassian-Lintzen, 1962). Such observations should be confirmed and controlled by scientific methods. Results from such an approach could be of greatest interest in respect of many unknown ecological factors. The same may be said in regard to the seasonal distribution of Iranian Tabanidae.

Practically nothing is known in Iran about the role of Tabanidae as transmitters of pathogenic agents (Trypanosoma evanisi, Anaplasma marginale, Leptospira icterohaemorrhagiae, Staphyllococcus albus and aureus, Bacillus anthracis, Pasteurella multo- 
cida, Pasteurella tularensis and several viruses). Four tabanid species: At. agrestis, At. pulchellus, Hyb. glaber and T. sufis, all known to be vectors of Tryp. evansi, are present in Iran and also in Khuzistan, from where (Dezful) Trypanosomiasis among horses has been observed as highly lethal by Carpentier in 1931 (Rafyi, 1952).

\section{SUMMARY}

67 species and 12 subspecies of Tabanidae have been found so far to occur in Iran. This list includes only records made by the writer and those reported in the litterature subsequent to 1958. Eight species (Das. umbrinus, H. sewelli, Ther. albicaudus, $T$. assuetus, $T$. bactrianus, $T$. olsufjevi, $T$. sordes and $T$. tergestinus) are here recorded for the first time in Iran. Atylotus theodori n. sp. and Chrysops flavipes gedrosiana n. subsp. are described. The taxonomic position of a few species previously reported is changed and two misidentifications ( $T$. taeniola and $T$. armeniacus) are corrected. Keys to all species and subspecies are presented and all known distributional data are included. Notes on bionomics are given and the zoogeography of the Iranian tabanid fauna is discussed, resulting in the conclusion that the fauna consists of a mixture of various faunistic elements mainly Palaearctic, three Ethio-asian and none Oriental.

\section{RESUME}

67 espèces et 12 sous-espèces de Tabanidae ont été trouvées jusqu'ici en Iran. Cette liste comprend seulement celles qui ont été collectées par l'auteur ou reportées dans la littérature depuis 1958. Huit espèces (Das. umbrinus, H. sewelli, Ther. albicaudus, $T$. assuetus, $T$. bactrianus, $T$. olsufjevi, $T$. sordes et $T$. tergestinus) ont été signalées pour la première fois en Iran. Atylotus theodori n. sp. et Chrysops flavipes gedrosiana n. spp. sont décrits. La position taxonomique de quelques espèces précédemment reportées est changée. Des clefs de détermination pour toutes les espèces et sous-espèces sont présentées et toutes données de distribution sont inclues. Quelques notes sur la bionomie sont données et la zoogéographie de la faune des Tabanidae de l'Iran est discutée avec la conclusion que cette faune consiste en un mélange de différents éléments faunistiques, essentiellement paléarctiques, trois éthio-asiatiques et aucun oriental.

\section{Références}

Abbassinn-Lintzen (R.), 1960 A. - Tabanidae (Diptera) of Iran. I. A review of literature. Arch. Inst. Razi, 12, 19-23.

- (-), 1960 B. - Idem. II. Records of horseflies in the Kazeroon area (province of Fars, southern Iran). Description of Silvius shapuricus n. sp. and Tabanus ansarii n. sp. Ibid., 12, 25-37.

- (-), 1960 C. - Idem. IV. Horseflies from the Demavend district in the Elburz Mountains. Bull. Soc. Path. exot,, 53, 819-824. 
- (-), 1960 D. - Idem. V. Description of three new subspecies of the genus Haematopota. Ibid., 53, 824-827.

- (-), 1961 A. - Idem. VI. Records of horseflies from southeast Iran (Iranian Baluchistan and the Jiroft area). Description of Tabanus kermani $\mathrm{n}$. sp. and Tabanus leclercqi n. sp. Ibid., 54, 128-147.

- (-), 1961 B. - Idem. VII. Additional records of horseflies from southeast Iran. Notes on Tabanus canipalpis, Bigot. Acta Med. Iran., 4, 12-19.

- (-), 1962. — Idem. VIII. A collection of horseflies from the province of Fars (southern Iran). Bull. Soc. Path. exot., 55, 443-46.

- (-), 1963. - Idem. XI. On the horsefly fauna of Khuzistan (southwest Iran). Ibid., 56, 77-88.

- (-), 1964. - Idem. IX. Horseflies from Azerbaijan (N.W. Iran). Ibid., 57, 164-173.

Austen (E. E.), 1919-20. - A contribution to knowledge of the Tabanidae of Palestine. Bull. ent. Res., 10, 277-321.

- (-), 1923-24. - Additional records of Palestinian Tabanidae with description of new species. Ibid., 14, 421-432.

Basu (B. C.), Balarama Menon (P.) and Sen Gupta (C. M.), 1952. - Regional distribution of Tabanus flies in India and its relationship to the incidence of Surra. Ind. J. vet. Sci. anim. Husb., 22, 273-292.

Bouvier (G.), 1945. - Les Tabanidés de la Suisse. Mitteilg. Schweiz. Ent. Ges., 29, 409-466.

Djafarov (Sh. M.), 1960. - Botflies (Diptera, Tabanidae) of Azerbaidjan. Zool. J. USSR, 39, 714-722 (In Russian).

Efflatoun Bey (H. C.), 1930. - A monograph of Egyptian Diptera, part III, Family Tabanidae. Mém. Soc. roy. ent. Egypte, 4, 1-114.

KRöBER (O.), 1925. - Tabanidae in Lindner: Die Fliegen der palaearktischen Region, 19, 1-146.

- (-), 1938. - Katalog der palaearktischen Tabaniden nebst Bestimmungstabellen und Zusätzen zu einzelnen Arten sowie Neubeschreibungen. Acta Inst. Mus. Zool. Univ. Athen., 2, 57-245.

LeClerce (M.), 1957. - Tabanidae (Dipt.) paléarctiques et africains, I. Verh. Naturf. Ges. Basel, 68, 65-67.

- (-), 1958. - Mission E. Janssens en Grèce, 1957, $2^{\circ}$ note: Diptera: Tabanidae. Bull. Ann. Soc. roy, ent. Belg., 94, 75-78.

- (-), 1960 A. - Révision des Nemorius Rondani (Dipt. Tabanidae), Nemorius abbassianae n. sp. Ibid., 96, 32-37.

- (-), 1960 B. - Révision des Sipala Enderlein (Dipt. Tabanidae) paléarctiques. Ibid., 96, 183-186.

- (一), 1960 C. - Tabanidae (Dipt.) d'Iran. III, Tabanus mofidii nova species. Arch. Inst. Razi, 12, 39-41.

- (-), 1960 D. - Révision systématique et biogéographique des Tabanidae (Diptera) paléarctiques. Volume I, Pangoniinae et Chrysopinae. Mém. Inst. roy. Sci. nat. Belg., 63, 1-77.

- (-), 1962. - Classification des Tabanus -s.str. paléarctiques et diagnoses des Tabanus 
briani et mouchaei n. sp. (Diptera Tabanidae). Bull. Inst. Agr. Stat. Rech. Gembloux, 30, 130-138.

- (-), 1963. - Tabanidae (Diptera) of Iraq. Bull. Iraq Nat. Hist. Inst., 2, 1-12.

Moucha (J.) and Chvala (M.), 1957. - Beitrag zur Kenntnis der Bremsen-Fauna (Dipt., Tabanidae) des östlichen Mittelmeergebietes. Ent. Zeitschr., 67, 1-7.

- (一), - (一), 1963 A. - Tabanidae (Diptera) collected by Dr. K. Lindberg in Afghanistan. Acta ent. Mus. nat. Pragae, 35, 521-525.

- (-), - (-), 1963 B. - Ergebnisse der Albanien-Expedition 1961 des deutschen entomologischen Institutes. Beitr. Ent., 13, 25-39.

OldRoYd (H.), 1954. - The Horse-flies of the Ethiopian Region. II. Tabanus and related genera. London, British, Museum, $341 \mathrm{p}$.

- (-), 1957. - The Horse-flies of the Ethiopian Region. III. Subfamilies Chrysopinae, Scepsidinae and Pangoniinae and a revised classification. London, British Museum, 489 p.

Olsufjev (N. G.), 1937. - Faune de 1'U.R.S.S., Insectes Diptères, VII, n 2, Fam. Tabanidae. Moscou et Léningrad, 434 p. (In Russian, German summary).

- (-), 1952. - New species of horseflies (Diptera, Tabanidae) of the fauna of USSR. Rev. d'ent. U.R.S.S., 32, 311-315. (In Russian).

- (-), 1962. - On the horse-flies (Tabanidae) in Altai Territory. Zool. J. USSR, 41, 882892. (In Russian, English summary).

- (-), and Melnikova (T. G.), 1962. - On the fauna of horseflies (Diptera, Tabanidae) in the Crimea. Rev. d'ent. URSS, 41, 576-578.

PhILIP (C. B.), 1952. - A collection of Tabanidae (Diptera) from the Dead Sea area of Palestine. Bull. Res. Counc. 1sr., 2, 2.

- (-), 1956. - Records of horseflies in Northeast Asia (Diptera, Tabanidae). Japan. J. sanitary Zool., 7, 221-230.

- (-), 1959. - Some records of Tabanidae (Dipt.) from Iran. Mitteilg. Schweiz. Ent. Ges., $32,333-336$.

- (-), 1961. - Notes on palaearctic Nemorius (Diptera: Tabanidae) with description of one new species. Bull. Ann. Soc. roy. Ent. Belg., 97, 225-236.

RaFYI (A.), 1952. - Protozoology. Tehran Univ. Press 134, 1-605. (In Persian).

Ricardo (G.), 1911. - A revision of the species of Tabanus from the Oriental Region, including notes on species from surrounding countries. Rec. Ind. Mus., 4, 111-258.

Shevshenko (V. V.), 1961. - Horseflies of Kazakistan. Publ. Acad. Sci. Kaz. SSR, AlmaAta, 1-228. (In Russian). 